Supporting Information For:

\title{
Uranyl oxo silylation promoted by silsesquioxane coordination
}

\author{
Mikiyas K. Assefa, Guang Wu, and Trevor W. Hayton* \\ Department of Chemistry and Biochemistry, University of California Santa Barbara, Santa \\ Barbara, CA 93106
}

*To whom correspondence should be addressed.Email: hayton@chem.ucsb.edu 


\section{Table of Contents}

$\begin{array}{ll}\text { Experimental Details } & \text { S3 }\end{array}$

$\begin{array}{ll}\text { NMR Spectra } & \text { S11 }\end{array}$

$\begin{array}{ll}\text { X-Ray Crystallographic Details } & \text { S36 }\end{array}$

$\begin{array}{ll}\text { Cyclic Voltammetry } & \text { S39 }\end{array}$

X-ray Photoelectron Spectroscopy $\quad$ S41

$\begin{array}{ll}\text { IR Spectra } & \text { S43 }\end{array}$

$\begin{array}{ll}\text { References } & \text { S47 }\end{array}$ 


\section{Experimental}

General Procedures. All reactions and subsequent manipulations were performed under anaerobic and anhydrous conditions in the glovebox or on the Schlenk line, under an atmosphere of dinitrogen. Hexanes, diethyl ether $\left(\mathrm{Et}_{2} \mathrm{O}\right)$, and tetrahydrofuran (THF) were dried by passage over activated molecular sieves using a Vacuum Atmospheres solvent purification system. Pentane and $\mathrm{CH}_{2} \mathrm{Cl}_{2}$ were dried and degassed on an $\mathrm{MBraun}$ solvent purification system, and stored over activated $3 \AA$ molecular sieves for $24 \mathrm{~h}$ prior to use. Acetonitrile $(\mathrm{MeCN})$ was dried over activated $3 \AA$ molecular sieves for $72 \mathrm{~h}$, and then degassed by bubbling dry $\mathrm{N}_{2}$ into the solvent for $30 \mathrm{~min}$, before being cannula transferred into a new vessel and again dried over $3 \AA$ molecular sieves for $24 \mathrm{~h}$ prior to use. $\mathrm{C}_{6} \mathrm{D}_{6}, \mathrm{CD}_{2} \mathrm{Cl}_{2}$, and THF-d 8 were dried over activated $3 \AA$ molecular sieves for $24 \mathrm{~h}$ prior to use. $\left[\mathrm{UO}_{2}\left(\mathrm{~N}\left(\mathrm{SiMe}_{3}\right)_{2}\right)_{2}(\mathrm{THF})_{2}\right],{ }^{1}[\mathrm{Li}(\mathrm{THF})]_{2}\left[\mathrm{U}\left(\mathrm{O}{ }^{t} \mathrm{Bu}\right)_{6}\right],{ }^{2}$ and $\left[\mathrm{N}\left(2,4-\mathrm{C}_{6} \mathrm{H}_{3} \mathrm{Br}_{2}\right)_{3}\right]\left[\mathrm{B}\left(\mathrm{C}_{6} \mathrm{~F}_{5}\right)_{4}\right]^{3}$ were prepared according to the reported literature procedures. All other reagents were purchased from commercial suppliers and used as received.

${ }^{1} \mathrm{H},{ }^{13} \mathrm{C}\left\{{ }^{1} \mathrm{H}\right\},{ }^{7} \mathrm{Li}\left\{{ }^{1} \mathrm{H}\right\}$ and ${ }^{29} \mathrm{Si}\left\{{ }^{1} \mathrm{H}\right\}$ NMR spectra were recorded on an Agilent Technologies 400 MHz 400-MR DD2 spectrometer or a Bruker AVANCE NEO 500 MHz NMR spectrometer equipped with a Prodigy coldprobe. ${ }^{1} \mathrm{H}$ and ${ }^{13} \mathrm{C}\left\{{ }^{1} \mathrm{H}\right\}$ NMR spectra were referenced to external $\mathrm{SiMe}_{4}$ using residual protio solvent resonances as internal standards. ${ }^{7} \mathrm{Li}\left\{{ }^{1} \mathrm{H}\right\}$ and ${ }^{29} \mathrm{Si}\left\{{ }^{1} \mathrm{H}\right\} \mathrm{NMR}$ spectra were referenced indirectly with the ${ }^{1} \mathrm{H}$ chemical shift of $\mathrm{SiMe}_{4}$ at $0 \mathrm{ppm}$, according to

IUPAC standard. ${ }^{4,5}$ IR spectra were recorded on a Nicolet 6700 FT-IR spectrometer. Elemental analyses were performed by the Microanalytical Laboratory at University of California (Berkeley, CA).

X-ray Crystallography. Data for 1-5 were collected on a Bruker KAPPA APEX II diffractometer equipped with an APEX II CCD detector using a TRIUMPH monochromater with 
a Mo K $\alpha$ X-ray source $(\alpha=0.71073 \AA)$. The crystals of $\mathbf{1 - 5}$ were mounted on a cryoloop under Paratone-N oil. Data for 1-2 were collected at 100(2) K, while data for 3-5 were collected at 110(2) K, using an Oxford nitrogen gas cryostream system. X-ray data for $\mathbf{1}$ and $\mathbf{2}$ were collected utilizing frame exposures of 5 and $20 \mathrm{~s}$, respectively, while $\mathbf{3}, \mathbf{4}$ and 5 utilized frame exposures of $60 \mathrm{~s}$. Data collection and cell parameter determination were conducted using the SMART program. ${ }^{6}$ Integration of the data frames and final cell parameter refinement were performed using SAINT software. ${ }^{7}$ Absorption corrections of the data were carried out using the multi-scan method SADABS. ${ }^{8}$ Subsequent calculations were carried out using SHELXTL. ${ }^{9}$ Structure determination was done using direct or Patterson methods and difference Fourier techniques. Unless stated otherwise, all hydrogen atom positions were idealized, and rode on the atom of attachment. Structure solution, refinement, graphics, and creation of publication materials were performed using SHELXTL or OLEX2. ${ }^{9,10}$

Complex 1 contains three cyclohexyl groups that exhibit positional disorder, which was resolved by modeling the affected atoms in two orientations in a 50:50 ratio using the PART command. Moreover, carbon atoms in the disordered cyclohexyl groups, and a disordered pentane solvate, were constrained with the SADI and EADP commands. Carbon atoms of the disordered pentane solvate were also refined isotropically.

Complex 2 contains five cyclohexyl groups, as well as three $\mathrm{MeCN}$ solvates and one $\mathrm{Et}_{2} \mathrm{O}$ solvate that exhibit disorder. This disorder was addressed by constraining the affected atoms with the SADI, EADP, and DFIX commands. In addition, the carbon atoms of seven other cyclohexyl groups were constrained with the EADP command. The $\mathrm{MeCN}$ and $\mathrm{Et}_{2} \mathrm{O}$ solvates were refined isotropically, and no hydrogen atoms were added to their carbon atoms. 
Complex 3 contains five cyclohexyl groups in the asymmetric unit that exhibit disorder. This disorder was resolved by constraining the affected atoms with the SADI and EADP commands. In addition, two of the five disordered cyclohexyl groups were modelled in two orientations in a 50:50 ratio using the PART command. Finally, three cyclohexyl groups in the asymmetric unit were disordered over two symmetry related positions. No hydrogens atoms were added to these cyclohexyl groups.

All cyclohexyl groups and THF molecules in complex 4 exhibit positional disorder, which was addressed by constraining the affected atoms with the SADI and EADP commands. Additionally, THF solvates were refined isotropically, and no hydrogen atoms were added to their carbon atoms.

Complex 5 contains three cyclohexyl groups that exhibit positional disorder, which was resolved by modeling the affected atoms in two orientations in a 50:50 ratio using the PART and EADP commands. Additionally, the two coordinated THF molecules and three other cyclohexyl groups were constrained with the EADP command. The structure of $\mathbf{5}$ also contains a disordered $\mathrm{CH}_{2} \mathrm{Cl}_{2}$ solvate, which was modelled in two orientations in a 50:50 ratio using the SADI, DFIX, and EQIV commands. As in 4, the $\mathrm{CH}_{2} \mathrm{Cl}_{2}$ solvate in $\mathbf{5}$ was refined isotropically, and no hydrogen atoms were added to its carbon atom.

Cyclic Voltammetry Measurements. CV experiments were performed with a CH Instruments 600c Potentiostat, and the data were processed using CHI software (version 6.29). All experiments were performed in a glove box using a $20 \mathrm{~mL}$ glass vial as the cell. The working electrode was glassy carbon ( $3 \mathrm{~mm}$ diameter), the counter electrode was a platinum wire, and the reference electrode was a silver wire electroplated with silver chloride. Solutions employed for 
CV studies were typically $1 \mathrm{mM}$ in analyte and $0.1 \mathrm{M}$ in $\left[\mathrm{NBu}_{4}\right]\left[\mathrm{PF}_{6}\right]$. All potentials are reported versus the $\left[\mathrm{Cp}_{2} \mathrm{Fe}\right]^{0 /+}$ couple.

X-ray Photoelectron Spectroscopy. XPS data were recorded using a Thermo Fisher Escalab $\mathrm{Xi}+$ spectrometer equipped with a monochromated Al-k alpha source $(1486 \mathrm{eV})$. Survey and high-resolution scans were recorded at $100 \mathrm{eV}$ and $20 \mathrm{eV}$ pass energies, respectively. A lowenergy electron flood was used for charge neutralization, and peak positions were calibrated against the aliphatic $\mathrm{C} 1 \mathrm{~s}$ peak $(285.0 \mathrm{eV})$.

Synthesis of $\left[\mathrm{U}\left(\mathrm{OSiMe}_{3}\right)_{3}\left(\mathrm{Cy}_{7} \mathrm{Si}_{7} \mathrm{O}_{12}\right)\right]$ (1): To a stirring orange solution of $\left[\mathrm{UO}_{2}\left(\mathrm{~N}\left(\mathrm{SiMe}_{3}\right)_{2}\right)_{2}(\mathrm{THF})_{2}\right](126.7 \mathrm{mg}, 0.172 \mathrm{mmol})$ in THF $(1 \mathrm{~mL})$ was added dropwise a colorless solution of $\mathrm{Cy}_{7} \mathrm{Si}_{7} \mathrm{O}_{9}(\mathrm{OH})_{3}(168.0 \mathrm{mg}, 0.173 \mathrm{mmol})$ in THF $(1 \mathrm{~mL})$. This addition resulted in an immediate color change to bright orange, concomitant with the deposition of a small amount of a fine yellow precipitate. The reaction mixture was stirred for $15 \mathrm{~min}$ at room temperature, whereupon the volatiles were removed in vacuo and the resulting tacky solid was triturated with pentane $(1 \mathrm{~mL})$ to yield an orange powder. The powder was extracted into 2:1 $\mathrm{Et}_{2} \mathrm{O} / \mathrm{MeCN}(2 \mathrm{~mL})$ and filtered through a Celite column supported on glass wool $(0.5 \mathrm{~cm} \times 2$ $\mathrm{cm})$ to yield an orange filtrate and a plug of yellow solid on the Celite. Storage of the filtrate at $25^{\circ} \mathrm{C}$ for $24 \mathrm{~h}$ resulted in deposition of orange plates which were isolated by decanting off the supernatant (60.1 mg, $24 \%$ yield). X-ray quality crystals of 1 were obtained from a concentrated pentane solution stored at $-25^{\circ} \mathrm{C}$ for $24 \mathrm{~h}$. Anal. Calcd for $\mathrm{C}_{51} \mathrm{H}_{104} \mathrm{O}{ }_{15} \mathrm{Si}_{10} \mathrm{U}$ : C, 41.49; H, 7.10. Found: $\mathrm{C}, 41.50 ; \mathrm{H}, 7.06 .{ }^{1} \mathrm{H}$ NMR $\left(\mathrm{C}_{6} \mathrm{D}_{6}, 25^{\circ} \mathrm{C}, 400 \mathrm{MHz}\right): \delta 0.46$ (s, 27H, Si-CH3), $1.02-$ 1.19 (m, 7H, overlapping Si-CH), 1.21-1.44 (br m, 20H, overlapping $\mathrm{CH}_{2}$ ), 1.56-1.82 (br m, 30H, overlapping $\left.\mathrm{CH}_{2}\right), 1.92\left(\mathrm{~m}, 6 \mathrm{H}\right.$, overlapping $\left.\mathrm{CH}_{2}\right), 2.13\left(\mathrm{~m}, 8 \mathrm{H}\right.$, overlapping $\left.\mathrm{CH}_{2}\right), 2.23(\mathrm{~m}$, 6H, overlapping $\left.\mathrm{CH}_{2}\right) .{ }^{13} \mathrm{C}\left\{{ }^{1} \mathrm{H}\right\}$ NMR $\left(\mathrm{C}_{6} \mathrm{D}_{6}, 25^{\circ} \mathrm{C}, 100 \mathrm{MHz}\right): \delta 3.79\left(\mathrm{OSi}^{-} \mathrm{CH}_{3}\right), 23.93(\mathrm{Si}-$ 
$\mathrm{CH}), 24.01(\mathrm{Si}-\mathrm{CH}), 26.53(\mathrm{Si}-\mathrm{CH}), 27.31\left(\mathrm{CH}_{2}\right), 27.37\left(\mathrm{CH}_{2}\right), 27.40\left(\mathrm{CH}_{2}\right), 27.54\left(\mathrm{CH}_{2}\right), 27.79$

$\left(\mathrm{CH}_{2}\right), 27.85\left(\mathrm{CH}_{2}\right), 27.91\left(\mathrm{CH}_{2}\right), 28.23\left(\mathrm{CH}_{2}\right) .{ }^{29} \mathrm{Si}\left\{{ }^{1} \mathrm{H}\right\}$ NMR $\left(\mathrm{C}_{6} \mathrm{D}_{6}, 25{ }^{\circ} \mathrm{C}, 79 \mathrm{MHz}\right): \delta-73.18$ (3Si, Si-CH), -69.06 (3Si, Si-CH), -68.12 (1 $\mathrm{Si}, \mathrm{Si}-\mathrm{CH}), 20.93$ (3Si, OSi-CH3). IR (KBr pellet, cm 1): 2922 (vs), 2850 (vs), 2667 (vw), 1448 (m, cyclohexyl H-C-H “scissor”), 1385 (vw), 1356 (vw), 1252 (m), 1248 (m), 1198 (m), 1122 (sh s, Si-O-Si stretch), 1078 (s, Si-O-Si stretch), 1026 (m), 997 (w), 847 (vs, Si-C stretch), 800 (m), 750 (w), 694 (vw), 640 (vw), 513 (s), 467 (m).

Synthesis of $\left[\left(\mathrm{UO}_{2}\right)_{3}\left(\mathrm{Cy}_{7} \mathrm{Si}_{7} \mathrm{O}_{12}\right)_{2}\left(\mathrm{MeCN}_{2}\left(\mathrm{Et}_{2} \mathrm{O}\right)\right](2)\right.$ : To a cold $\left(-25^{\circ} \mathrm{C}\right)$ stirring orange solution of $\left[\mathrm{UO}_{2}\left(\mathrm{~N}\left(\mathrm{SiMe}_{3}\right)_{2}\right)_{2}(\mathrm{THF})_{2}\right](169.3 \mathrm{mg}, 0.230 \mathrm{mmol})$ in hexanes $(3 \mathrm{~mL})$ was added dropwise a cold $\left(-25^{\circ} \mathrm{C}\right)$ slurry of $\mathrm{Cy}_{7} \mathrm{Si}_{7} \mathrm{O}_{9}(\mathrm{OH})_{3}(150.0 \mathrm{mg}, 0.154 \mathrm{mmol})$ in hexanes $(3 \mathrm{~mL})$ over a course of $15 \mathrm{~min}$. This addition resulted in an immediate color change to dark brown, and then gradually to bright yellow. The resulting slurry was stirred for $15 \mathrm{~min}$ at room temperature, whereupon the volatiles were removed in vacuo to yield a yellow powder. The powder was extracted into $\mathrm{Et}_{2} \mathrm{O}(2 \mathrm{~mL})$ and filtered through a Celite column supported on glass wool $(0.5 \mathrm{~cm}$ $\times 2 \mathrm{~cm}$ ) to yield a yellow filtrate. The filtrate was then transferred to a $4 \mathrm{~mL}$ vial, which was subsequently placed inside a $20 \mathrm{~mL}$ scintillation vial. Acetonitrile $(1 \mathrm{~mL})$ was added to the outer vial. Storage of the two-vial system at $-25^{\circ} \mathrm{C}$ for $48 \mathrm{~h}$ resulted in deposition of yellow plates which were isolated by decanting off the supernatant ( $94.3 \mathrm{mg}, 42 \%$ yield). Anal. Calcd for $\mathrm{C}_{92} \mathrm{H}_{170} \mathrm{~N}_{2} \mathrm{O}_{31} \mathrm{Si}_{14} \mathrm{U}_{3}: \mathrm{C}, 38.00 ; \mathrm{H}, 5.89 ; \mathrm{N}, 0.96$. Found: C, 38.39; H, 6.18; N, 0.88. ${ }^{1} \mathrm{H}$ NMR (THF-d $8,25^{\circ} \mathrm{C}, 500 \mathrm{MHz}$ ): $\delta 0.60-1.07$ (br m, 20H, overlapping Si-CH and $\mathrm{CH}_{2}$ ), 1.11 (t, $6 \mathrm{H}$, $\mathrm{OCH}_{2} \mathrm{CH}_{3}$ ), $1.14-1.56$ (br m, 68H, overlapping $\mathrm{CH}_{2}$ ), 1.57 - 1.93 (br m, 66H, overlapping $\mathrm{CH}_{2}$ ), 1.94 (s, 6H, $\mathrm{CH}_{3} \mathrm{CN}$ ), 3.37 (q, 4H, OCH ${ }_{2}$. ${ }^{29} \mathrm{Si}\left\{{ }^{1} \mathrm{H}\right\} \mathrm{NMR}$ (THF-d $\left.8,25{ }^{\circ} \mathrm{C}, 99 \mathrm{MHz}\right): \delta-$ 72.07 (br), -70.27, -70.15, -69.24, -68.11, -67.81, -67.55 (br). IR (KBr pellet, $\mathrm{cm}^{-1}$ ): 2920 (s), 2848 (s), 2665 (vw), 1618 (vw), 1448 (s, cyclohexyl H-C-H “scissor”), 1389 (vw), 1356 (vw), 
1327 (vw), 1269 (m), 1196 (m), 1147 (br m, Si-O-Si stretch), 1026 (vw), 999 (vw), 978 (vw), 916 (sh w), 912 (sh w), 893 (w), 847 (s), 823 (m), 752 (m), 640 (w), 588 (vw), 582 (w), 513 (vs), $467(\mathrm{~m}), 445(\mathrm{~m}), 418(\mathrm{~s})$.

Synthesis of $\left[\mathbf{L i}(\mathbf{T H F})_{2}\right]_{2}\left[\mathbf{U}\left(\mathrm{Cy}_{7} \mathrm{Si}_{7} \mathbf{O}_{12}\right)_{2}\right]$ (4): A pale blue solution of $[\mathrm{Li}(\mathrm{THF})]_{2}\left[\mathrm{U}\left(\mathrm{O}^{t} \mathrm{Bu}\right)_{6}\right]^{2}$ (260.1 mg, $0.312 \mathrm{mmol})$ in THF $(4 \mathrm{~mL})$ was layered onto a colorless solution of $\mathrm{Cy}_{7} \mathrm{Si}_{7} \mathrm{O}_{9}(\mathrm{OH})_{3}$ (604.2 $\mathrm{mg}, 0.621 \mathrm{mmol})$ in THF $(3 \mathrm{~mL})$. The resulting mixture was allowed to stand undisturbed for $48 \mathrm{~h}$ at room temperature, which resulted in deposition of pale pink plates. The crystals were isolated by decanting off the supernatant and dried in vacuo $(445.4 \mathrm{mg})$. Concentration of the supernatant, followed by storage at $-25^{\circ} \mathrm{C}$ for $48 \mathrm{~h}$, afforded a second crop of crystals (total yield: $568.2 \mathrm{mg}, 74 \%$ ). X-ray quality crystals of 4 were grown from a hot THF solution that was allowed to slowly cool to room temperature overnight. Anal. Calcd for $\mathrm{C}_{100} \mathrm{H}_{186} \mathrm{Li}_{2} \mathrm{O}_{28} \mathrm{Si}_{14} \mathrm{U}$ : C, 48.39; H, 7.55; Found: C, 47.97; H, 7.34. IR (KBr pellet, $\mathrm{cm}^{-1}$ ): 2920 (vs), 2848 (vs), 2665 (vw), 1618 (vw), 1460 (sh w), 1446 (vs, cyclohexyl H-C-H “scissor”), 1396 (w), 1346 (vw), 1300 (vw), 1282 (sh w), 1267 (m), 1196 (s, Si-O-Si stretch), 1134 (s, Si-O-Si stretch), 1076 (br s, SiO-Si stretch), 1039 (m), 1026 (m), 997 (m), 945 (s), 922 (s), 893 (vs), 849 (s), 823 (m), 744 (w), 739 (m), 677 (br vw), 638 (w), 615 (vw), 567 (vw), $536(\mathrm{~m}), 515$ (s), 471 (m), $411(\mathrm{~m})$.

Synthesis of $\left[\mathbf{L i}(\mathbf{T H F})_{2}\right]\left[\mathbf{U}\left(\mathbf{C y}_{7} \mathbf{S i}_{7} \mathbf{O}_{12}\right)_{2}\right]$ (5): To a stirring pink slurry of 4 (568.2. $\mathrm{mg}, 0.229$ mmol) in THF (4 mL) was added an orange-brown solution of $\mathrm{I}_{2}(29.1 .2 \mathrm{mg}, 0.115 \mathrm{mmol})$ in THF $(2 \mathrm{~mL})$. The resulting orange-brown mixture was allowed to stir for $1 \mathrm{~h}$ at room temperature, which resulted in dissolution of $\mathbf{4}$ and a color change to pale yellow, concomitant with deposition of a pale yellow solid. The volume of the mixture was reduced to $\sim 4 \mathrm{~mL}$ in vacuo, and the resulting solution was warmed until all the yellow solid dissolved. The resulting pale yellow solution was layered with $\mathrm{Et}_{2} \mathrm{O}(4 \mathrm{~mL})$ and stored at $-25^{\circ} \mathrm{C}$ for $24 \mathrm{~h}$, which resulted 
in deposition a pale yellow microcrystalline solid $(476.3 \mathrm{mg}, 89 \%$ yield). X-ray quality crystals of 5 were obtained from a concentrated $\mathrm{CH}_{2} \mathrm{Cl}_{2}$ solution stored at $-25{ }^{\circ} \mathrm{C}$ for $24 \mathrm{~h}$. Anal. Calcd for $\mathrm{C}_{92} \mathrm{H}_{170} \mathrm{LiO}_{26} \mathrm{Si}_{14} \mathrm{U}: \mathrm{C}, 47.41 ; \mathrm{H}, 7.35$. Found: $\mathrm{C}, 47.41 ; \mathrm{H}, 7.21{ }^{1} \mathrm{H}$ NMR $\left(\mathrm{CD}_{2} \mathrm{Cl}_{2}, 25{ }^{\circ} \mathrm{C}\right.$, $400 \mathrm{MHz}$ ): $\delta 0.60-1.12$ (br m, 46H, overlapping Si-CH and $\mathrm{CH}_{2}$ ), $1.13-1.50$ (br m, 54H, overlapping $\mathrm{CH}_{2}$ ), $1.51-1.87$ (br m, 54H, overlapping $\mathrm{CH}_{2}$ ), 1.94 (br m, $8 \mathrm{H}, \mathrm{OCH}_{2} \mathrm{CH}_{2}$ ), 3.89 (br m, 8H, $\left.\mathrm{OCH}_{2} \mathrm{CH}_{2}\right) .{ }^{13} \mathrm{C}\left\{{ }^{1} \mathrm{H}\right\} \mathrm{NMR}\left(\mathrm{CD}_{2} \mathrm{Cl}_{2}, 25{ }^{\circ} \mathrm{C}, 100 \mathrm{MHz}\right): 24.66\left(\mathrm{OCH}_{2} \mathrm{CH}_{2}\right), 26.18$ (Si$\mathrm{CH}), 27.25(\mathrm{Si}-\mathrm{CH}), 27.39(\mathrm{Si}-\mathrm{CH}), 27.48\left(\mathrm{CH}_{2}\right), 27.55\left(\mathrm{CH}_{2}\right), 28.21\left(\mathrm{CH}_{2}\right), 28.74\left(\mathrm{CH}_{2}\right), 69.65$ $\left(\mathrm{OCH}_{2} \mathrm{CH}_{2}\right) .{ }^{7} \mathrm{Li}\left\{{ }^{1} \mathrm{H}\right\}$ NMR $\left(\mathrm{CD}_{2} \mathrm{Cl}_{2}, 25{ }^{\circ} \mathrm{C}, 155 \mathrm{MHz}\right): 1.52$ (br s, $\left.1 \mathrm{Li}\right) .{ }^{29} \mathrm{Si}\left\{{ }^{1} \mathrm{H}\right\} \mathrm{NMR}\left(\mathrm{CD}_{2} \mathrm{Cl}_{2}\right.$, $\left.25^{\circ} \mathrm{C}, 79 \mathrm{MHz}\right): \delta-69.86(3 \mathrm{Si}),-67.94(1 \mathrm{Si})$. A resonance assignable to the three Si nuclei in the environment nearest to the $\mathrm{U}(\mathrm{V})$ center was not observed, likely due to paramagnetic broadening. IR (KBr pellet, $\mathrm{cm}^{-1}$ ): 2922 (vs), 2848 (vs), 2665 (vw), 1637 (w), 1460 (sh w), 1446 (m, cyclohexyl H-C-H “scissor”), 1356 (vw), 1346 (vw), 1267 (m), 1196 (m), 1130 (s, Si-O-Si stretch), 1080 (s, Si-O-Si stretch), 1038 (w), 1026 (w), 997 (w), 922 (vs), 895 (vs), 849 (m), 825 (w), 756 (sh w), 741 (w), 640 (vw), 534 (vw), 513 (w), $471(\mathrm{w}), 411(\mathrm{w})$.

Synthesis of $\left[\mathbf{U}\left(\mathrm{Cy}_{7} \mathbf{S i}_{7} \mathbf{O}_{12}\right)_{2}\right]$ (3): To a stirring colorless solution of $\mathbf{5}(27.6 \mathrm{mg}, 0.012 \mathrm{mmol})$ in $\mathrm{CH}_{2} \mathrm{Cl}_{2}(1 \mathrm{~mL})$ was added a deep green solution of $\left[\mathrm{N}\left(2,4-\mathrm{C}_{6} \mathrm{H}_{3} \mathrm{Br}_{2}\right)_{3}\right]\left[\mathrm{B}\left(\mathrm{C}_{6} \mathrm{~F}_{5}\right)_{4}\right]^{3}(22.1 \mathrm{mg}$, $0.016 \mathrm{mmol}, 1.3$ equiv) in $\mathrm{CH}_{2} \mathrm{Cl}_{2}(1 \mathrm{~mL})$. This addition resulted in an immediate color change, first to pale yellow and then to green. The resulting mixture was stirred for $5 \mathrm{~min}$ at room temperature, whereupon the volatiles were removed in vacuo to yield a mixture of yellow and green solids. The residue was extracted into hexanes $(2 \times 2 \mathrm{~mL})$ and filtered through a Celite column supported on glass wool $(0.5 \mathrm{~cm} \times 2 \mathrm{~cm})$ to yield a pale yellow filtrate and a plug of green solid on the Celite. The volatiles were removed from the filtrate in vacuo to give a pale yellow solid. This solid was then dissolved in $\mathrm{C}_{6} \mathrm{D}_{6}(0.75 \mathrm{~mL})$ and the ${ }^{1} \mathrm{H}$ and ${ }^{29} \mathrm{Si}\left\{{ }^{1} \mathrm{H}\right\}$ NMR 
spectra were recorded. X-ray quality crystals of $\mathbf{3}$ were obtained from slow evaporation of a concentrated pentane solution at room temperature. Unfortunately, pure samples of $\mathbf{3}$ could not be isolated due to its similar solubility with the $\mathrm{N}\left(2,4-\mathrm{C}_{6} \mathrm{H}_{3} \mathrm{Br} 2\right)_{3}$ by-product. ${ }^{1} \mathrm{H}$ NMR $\left(\mathrm{C}_{6} \mathrm{D}_{6}, 25\right.$ $\left.{ }^{\circ} \mathrm{C}, 400 \mathrm{MHz}\right): \delta 0.95-1.54$ (m, 66H, overlapping $\mathrm{Si}-\mathrm{CH}$ and $\left.\mathrm{CH}_{2}, 3\right), 1.55-1.88(\mathrm{~m}, 54 \mathrm{H}$, overlapping $\left.\mathrm{CH}_{2}, 3\right), 1.89-2.29$ (m, 34H, overlapping $\left.\mathrm{CH}_{2}, 3\right), 6.16\left(\mathrm{~d}, \mathrm{~J}_{\mathrm{HH}}=8 \mathrm{~Hz}, 3 \mathrm{H}\right.$, aryl $\left.\mathrm{CH}, \mathrm{N}\left(2,4-\mathrm{C}_{6} \mathrm{H}_{3} \mathrm{Br}_{2}\right)_{3}\right), 6.96\left(\mathrm{dd}, J_{\mathrm{HH}}=8,3 \mathrm{~Hz}, 3 \mathrm{H}, \operatorname{aryl~CH}, \mathrm{N}\left(2,4-\mathrm{C}_{6} \mathrm{H}_{3} \mathrm{Br}_{2}\right)_{3}\right), 7.55\left(\mathrm{~d}, J_{\mathrm{HH}}=4\right.$ $\mathrm{Hz}, 3 \mathrm{H}$, aryl $\left.\mathrm{CH}, \mathrm{N}\left(2,4-\mathrm{C}_{6} \mathrm{H}_{3} \mathrm{Br}_{2}\right)_{3}\right) .{ }^{29} \mathrm{Si}\left\{{ }^{1} \mathrm{H}\right\} \mathrm{NMR}\left(\mathrm{C}_{6} \mathrm{D}_{6}, 25^{\circ} \mathrm{C}, 79 \mathrm{MHz}\right): \delta$-74.40 (3Si), $69.04(3 \mathrm{Si}),-68.17(1 \mathrm{Si})$. 


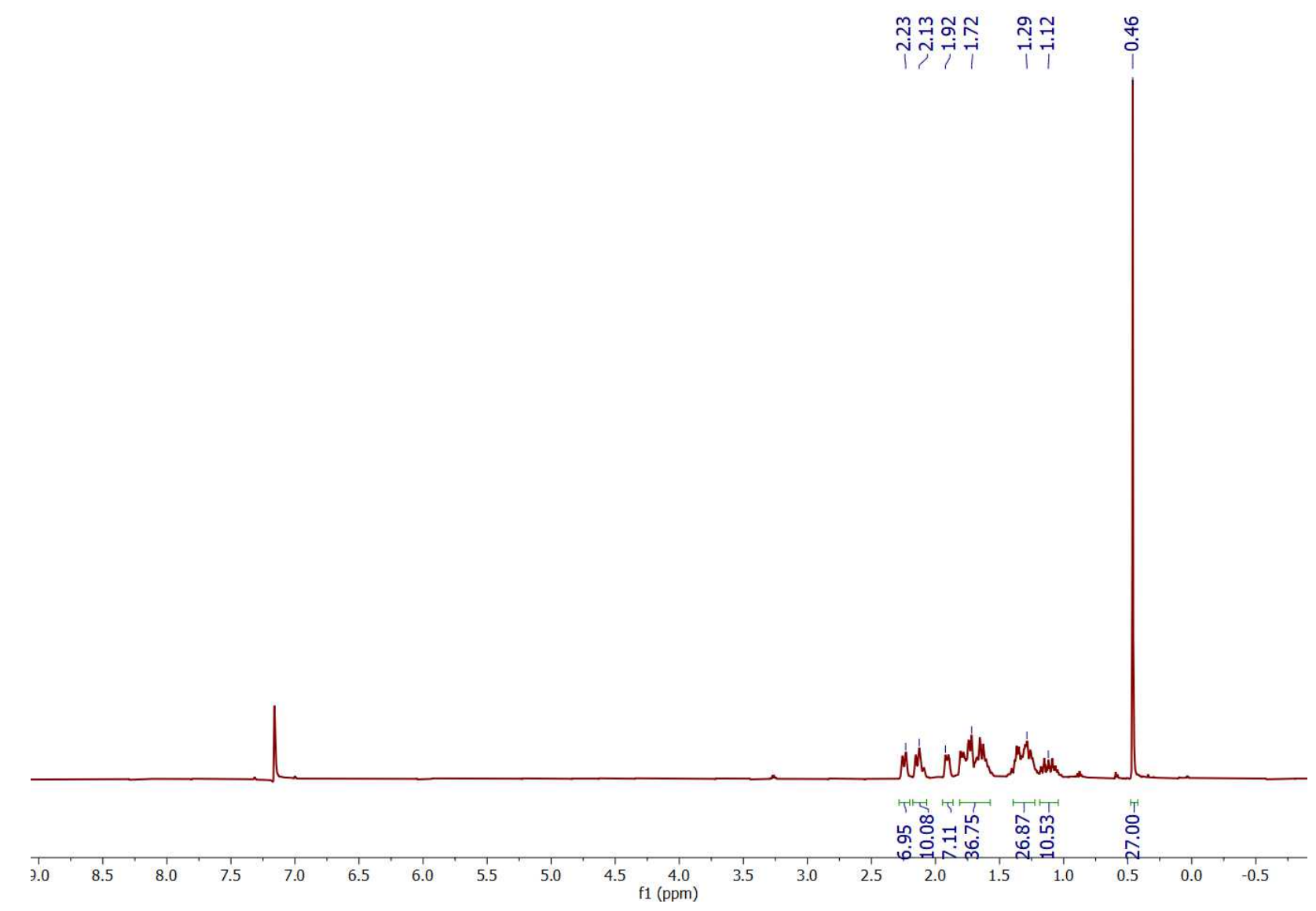

Figure S1. ${ }^{1} \mathrm{H}$ NMR spectrum of 1 in $\mathrm{C}_{6} \mathrm{D}_{6}$. 

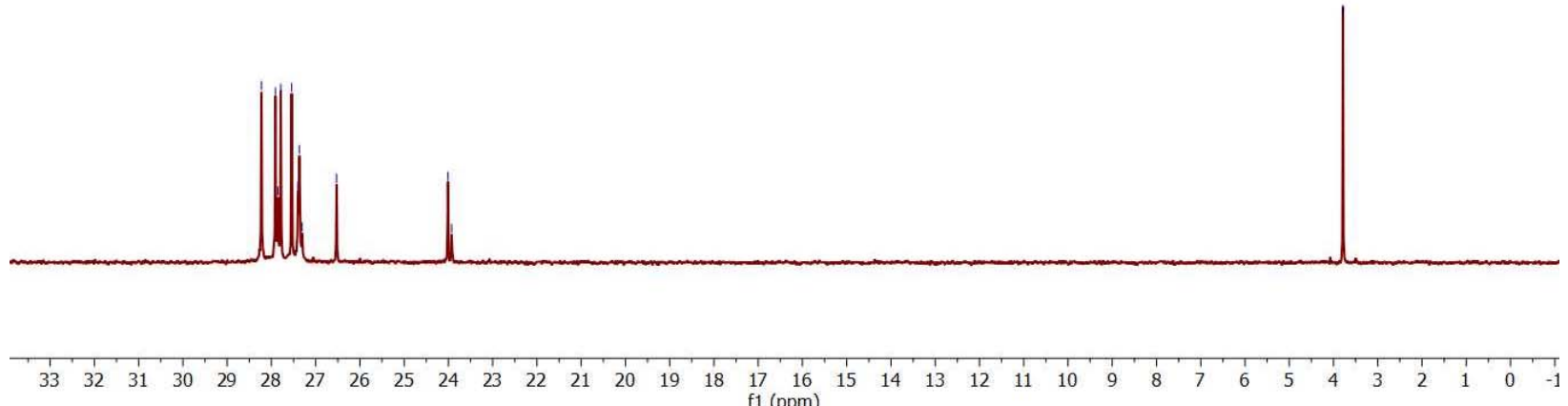

Figure S2. ${ }^{13} \mathrm{C}\left\{{ }^{1} \mathrm{H}\right\}$ NMR spectrum of $\mathbf{1}$ in $\mathrm{C}_{6} \mathrm{D}_{6}$. 


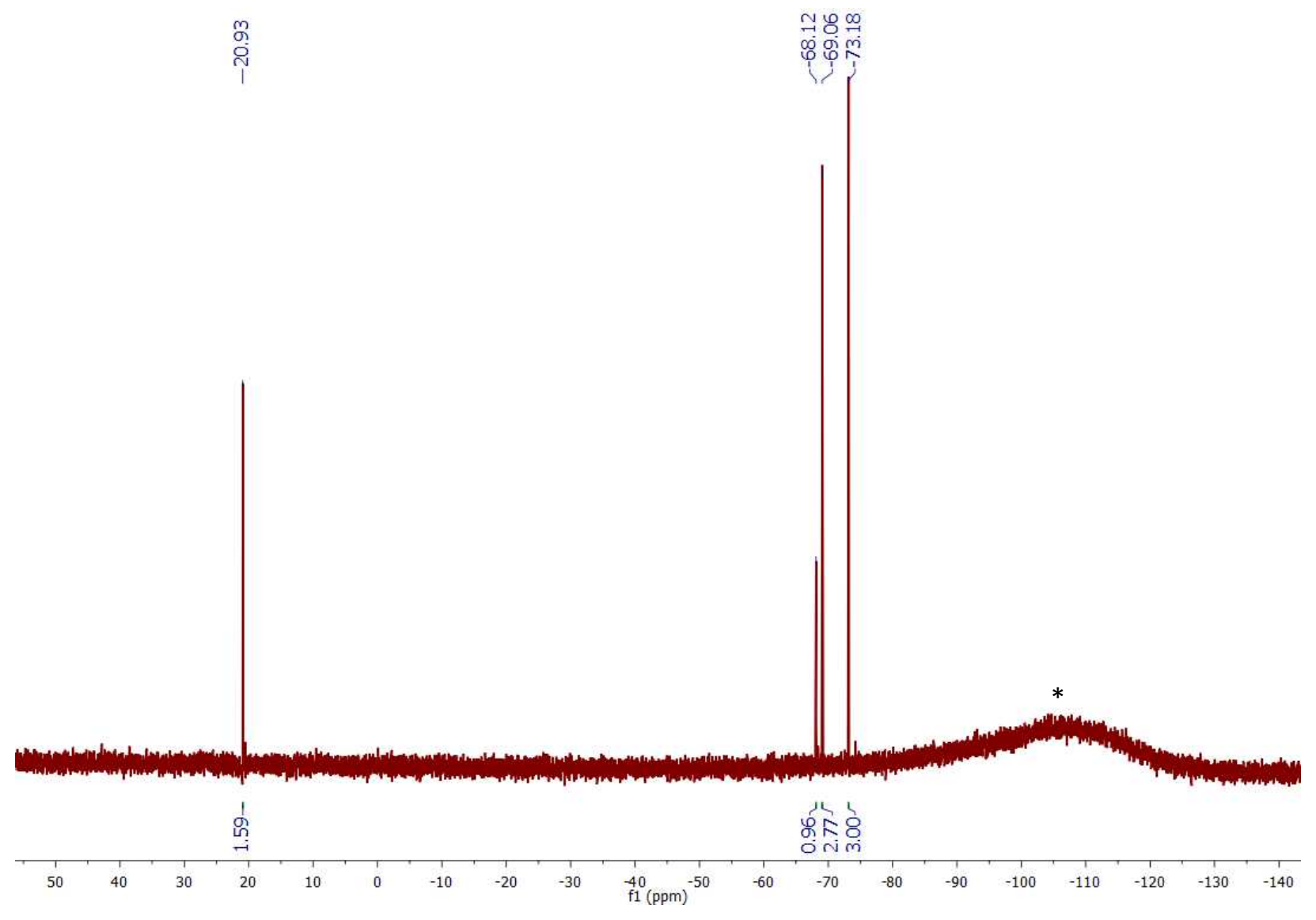

Figure S3. ${ }^{29} \mathrm{Si}\left\{{ }^{1} \mathrm{H}\right\}$ NMR spectrum of 1 in $\mathrm{C}_{6} \mathrm{D}_{6}$. * indicates resonances assignable to $\mathrm{SiO}_{2}$ present in the NMR tube. 


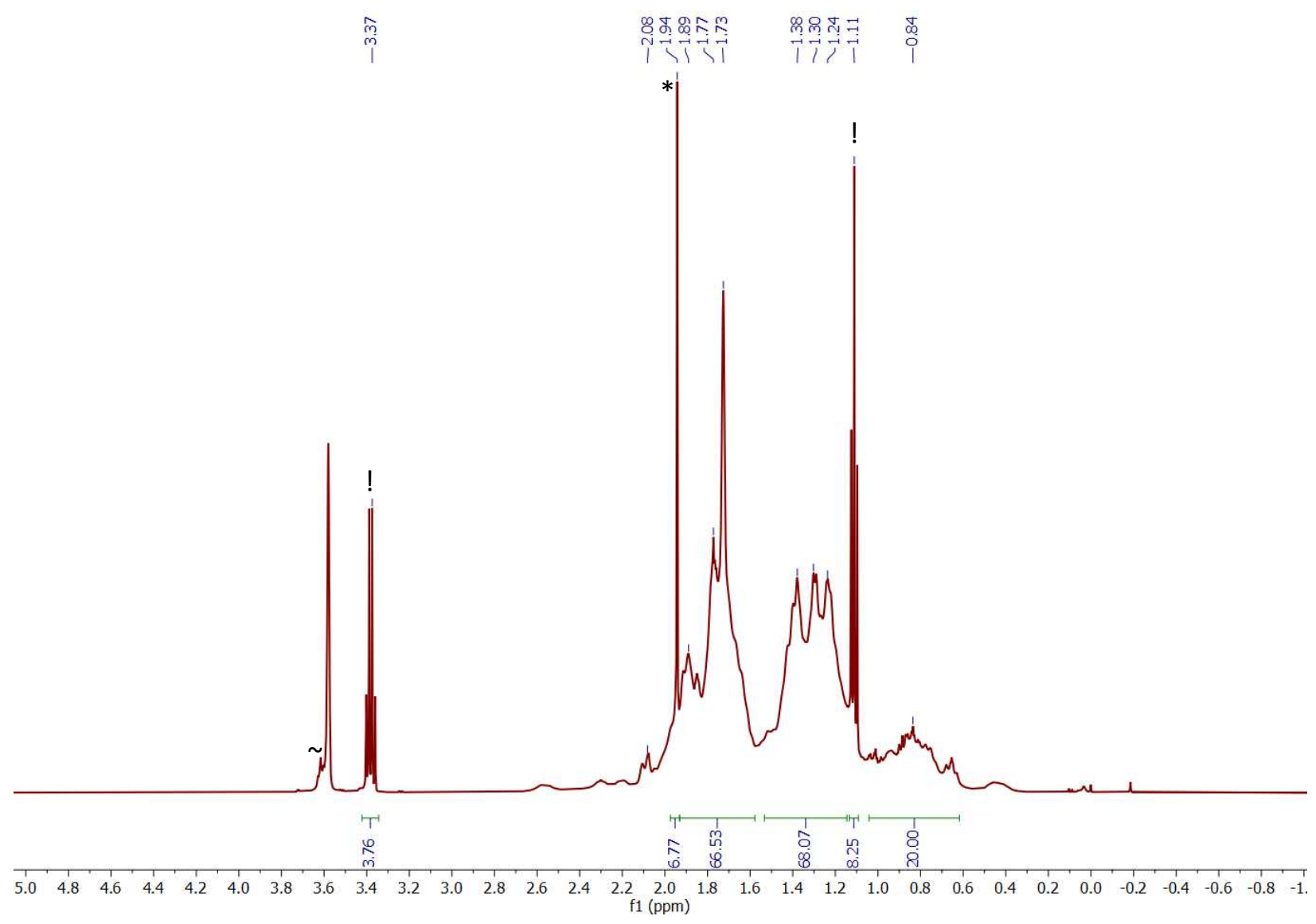

Figure S4. ${ }^{1} \mathrm{H}$ NMR spectrum of 2 in THF-d8. (*) indicates resonances assignable to MeCN, $(\sim)$ indicates resonances assignable to THF, and (!) indicates resonances assignable to $\mathrm{Et}_{2} \mathrm{O}$. 


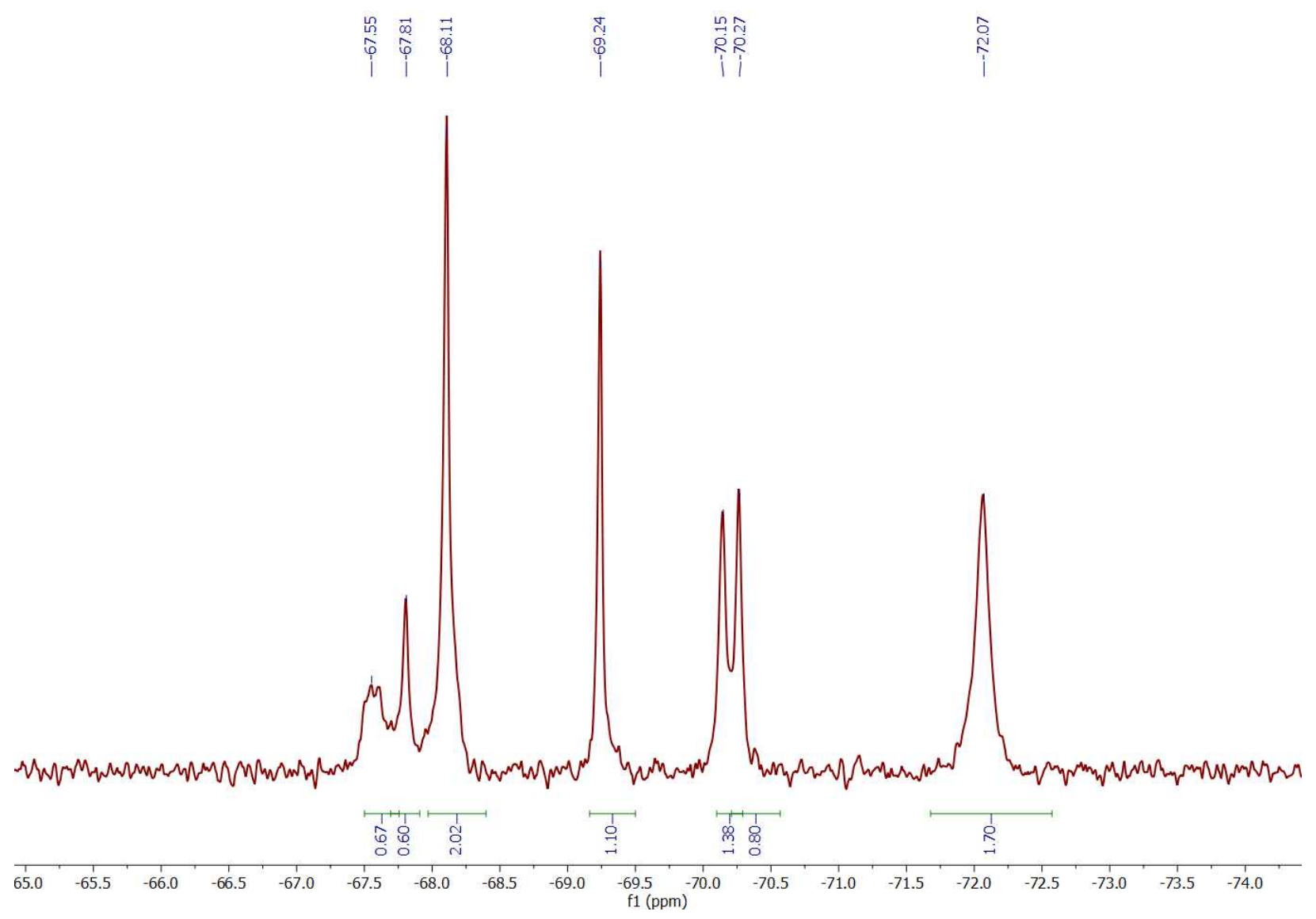

Figure S5. ${ }^{29} \mathrm{Si}\left\{{ }^{1} \mathrm{H}\right\}$ NMR spectrum of 2 in THF- $d_{8}$. 


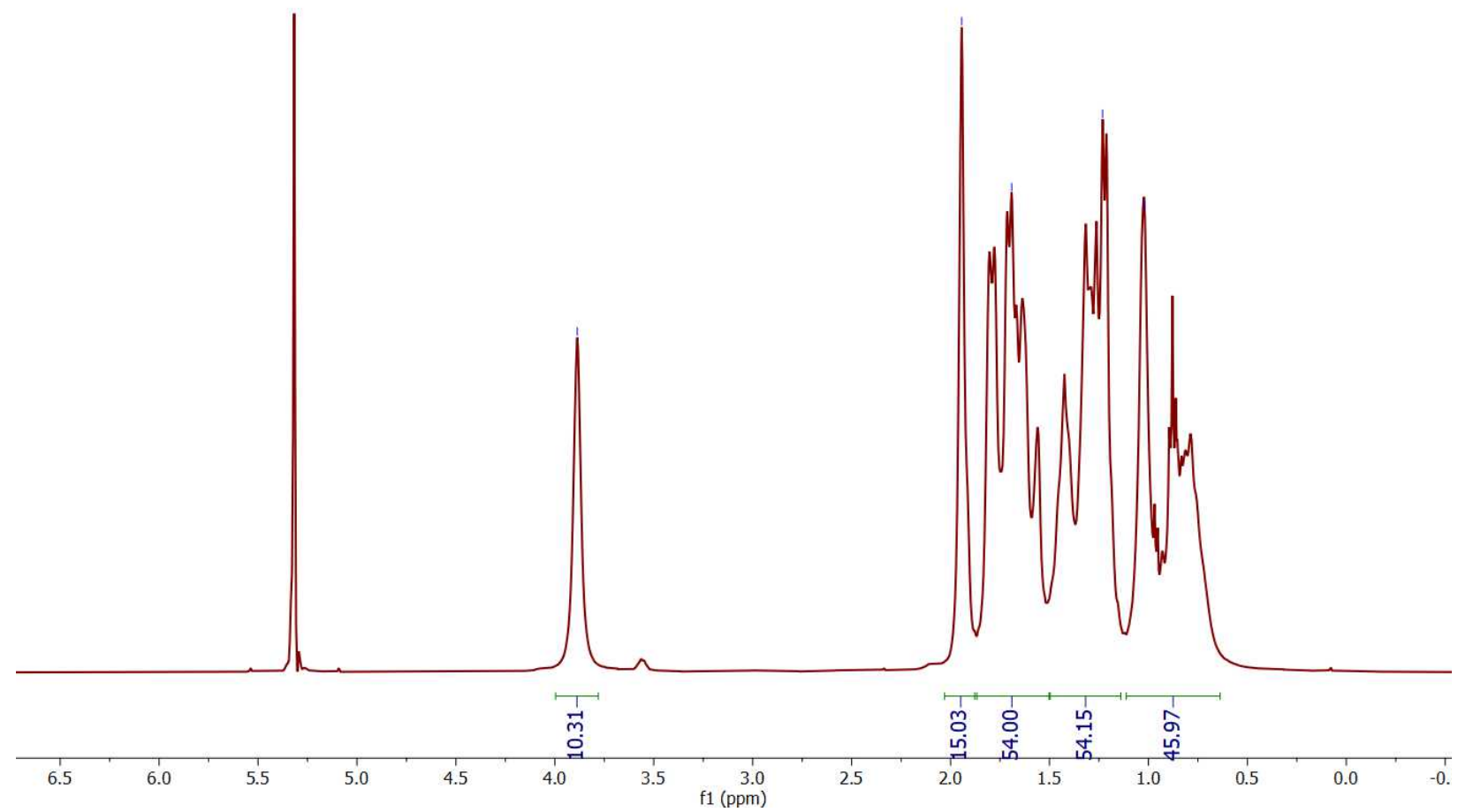

Figure S6. ${ }^{1} \mathrm{H}$ NMR spectrum of 5 in $\mathrm{CD}_{2} \mathrm{Cl}_{2}$. 


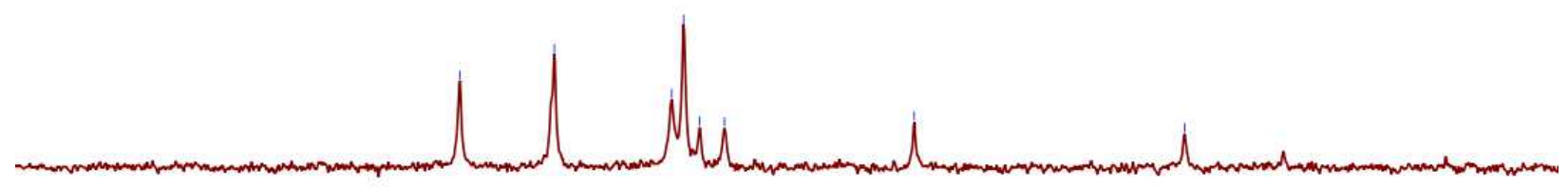

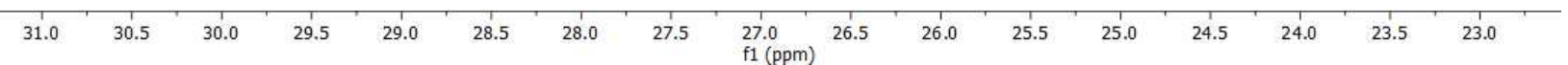

Figure S7. ${ }^{13} \mathrm{C}\left\{{ }^{1} \mathrm{H}\right\}$ NMR spectrum of 5 in $\mathrm{CD}_{2} \mathrm{Cl}_{2}$. 


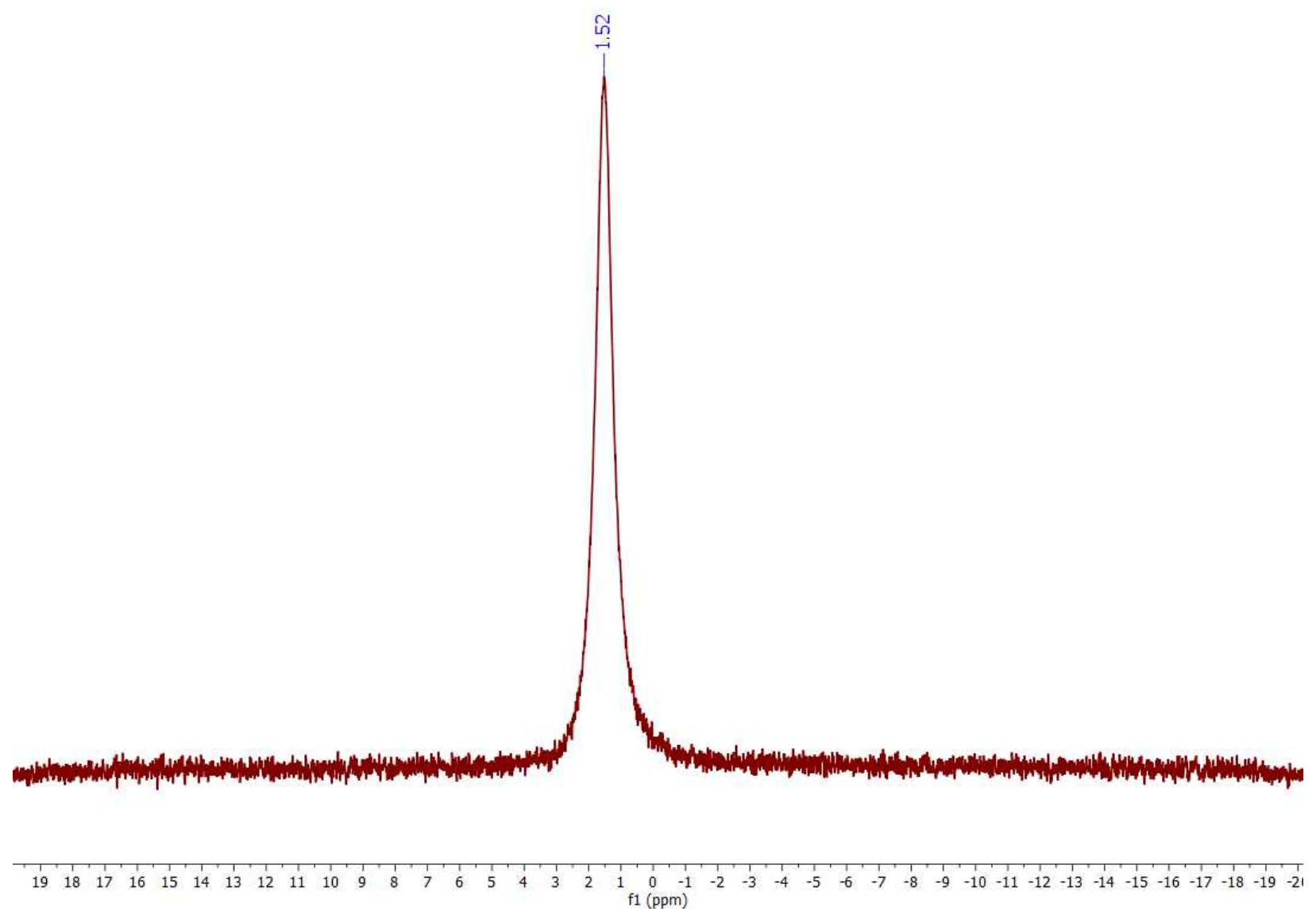

Figure S8. ${ }^{7} \mathrm{Li}\left\{{ }^{1} \mathrm{H}\right\} \mathrm{NMR}$ spectrum of 5 in $\mathrm{CD}_{2} \mathrm{Cl}_{2}$. 


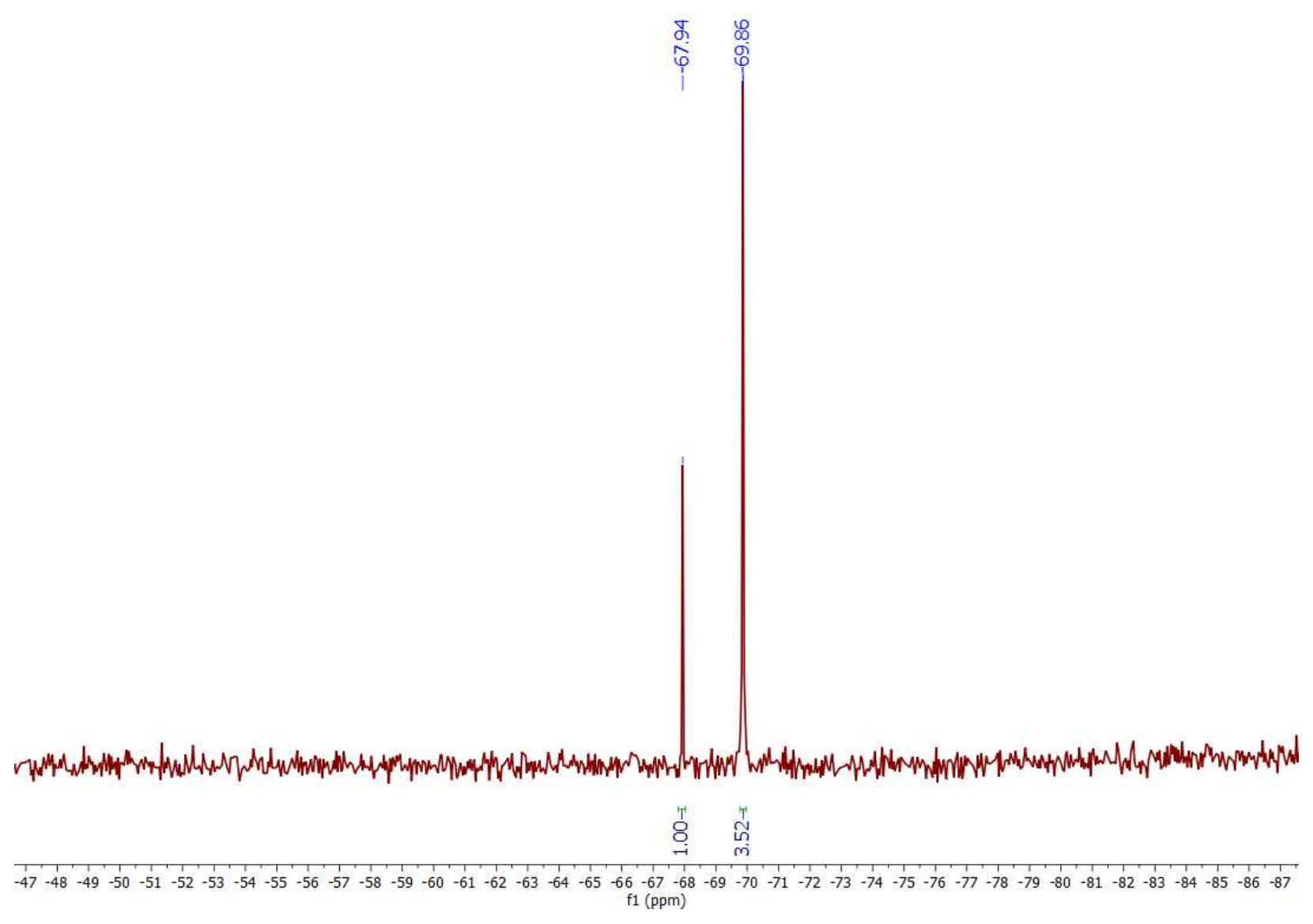

Figure S9. ${ }^{29} \mathrm{Si}\left\{{ }^{1} \mathrm{H}\right\}$ NMR spectrum of 5 in $\mathrm{CD}_{2} \mathrm{Cl}_{2}$. 


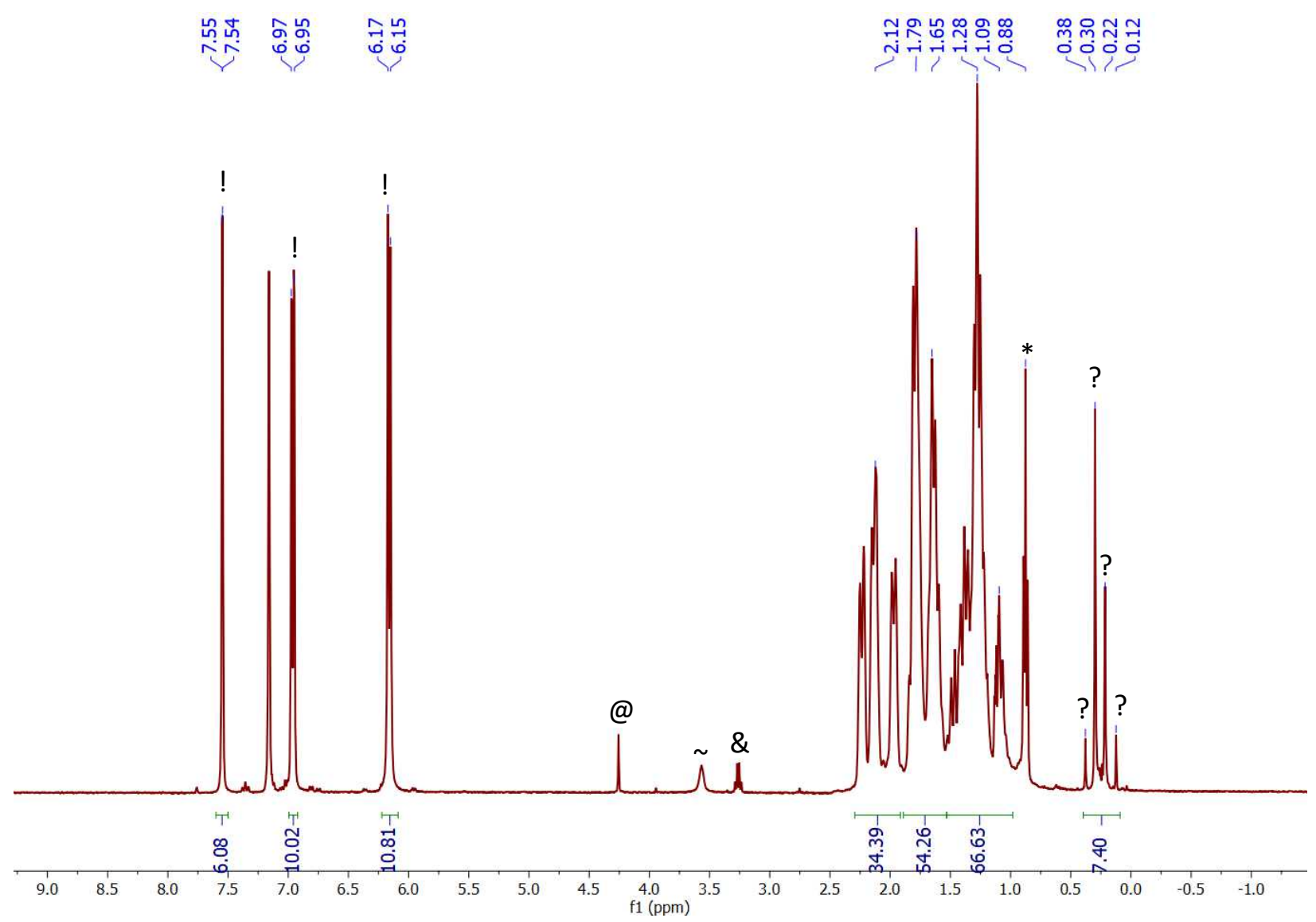

Figure S10. ${ }^{1} \mathrm{H}$ NMR spectrum (in $\left.\mathrm{C}_{6} \mathrm{D}_{6}\right)$ of a mixture of 3 and $\mathrm{N}\left(2,4-\mathrm{C}_{6} \mathrm{H}_{3} \mathrm{Br}_{2}\right)_{3}$. (!) indicates resonances assignable to $\mathrm{N}\left(2,4-\mathrm{C}_{6} \mathrm{H}_{3} \mathrm{Br}_{2}\right)_{3}$, * indicates resonances assignable to hexanes, @ indicates resonances assignable to $\mathrm{CH}_{2} \mathrm{Cl}_{2}, \&$ indicates resonances assignable to $\mathrm{Et}_{2} \mathrm{O}, \sim$ indicates resonances assignable to THF, and (?) indicates resonances assignable to unidentified products. 


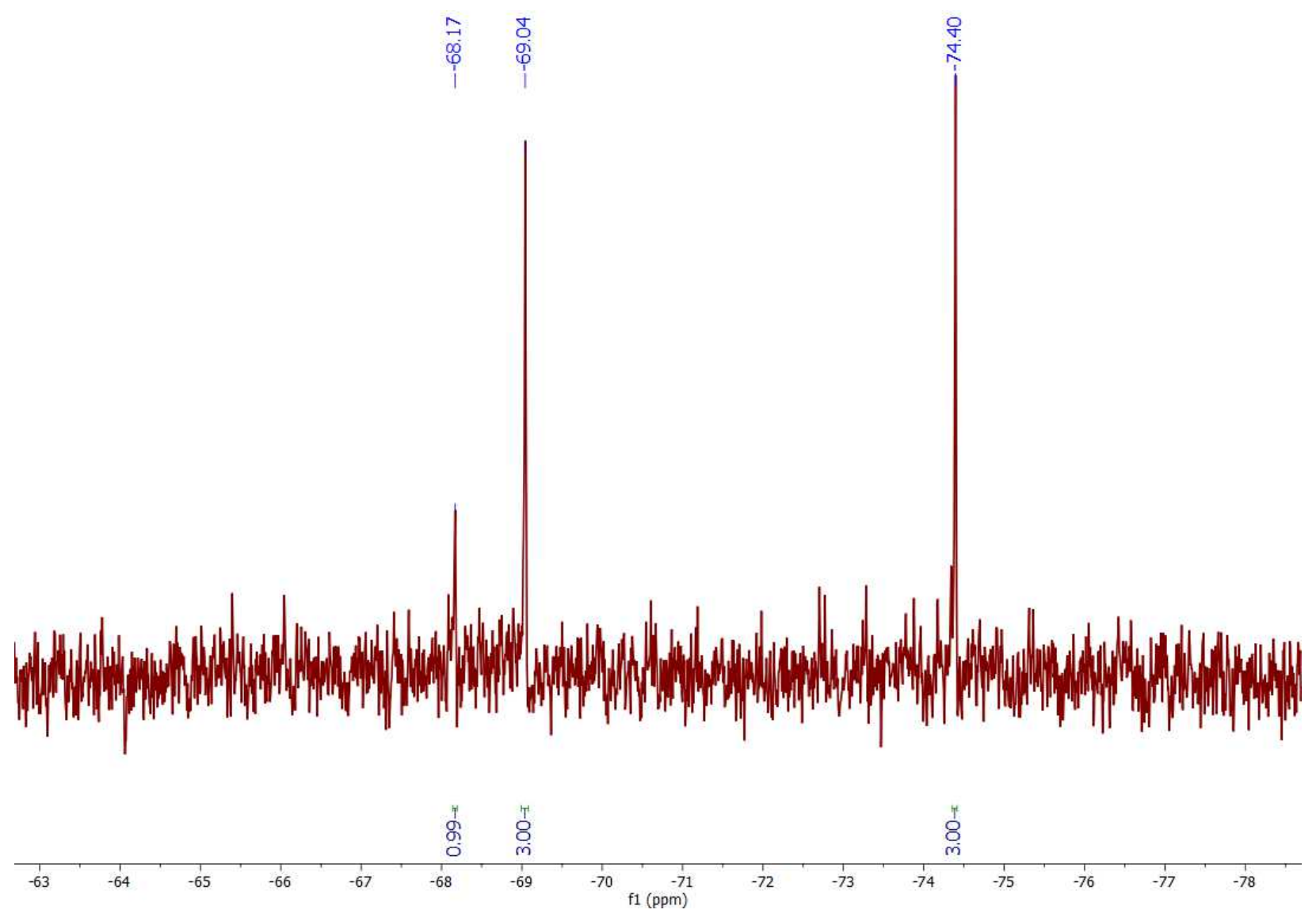

Figure S11. ${ }^{29} \mathrm{Si}\left\{{ }^{1} \mathrm{H}\right\}$ NMR spectrum (in $\left.\mathrm{C}_{6} \mathrm{D}_{6}\right)$ of a mixture of $\mathbf{3}$ and $\mathrm{N}\left(2,4-\mathrm{C}_{6} \mathrm{H}_{3} \mathrm{Br}_{2}\right)_{3}$. 


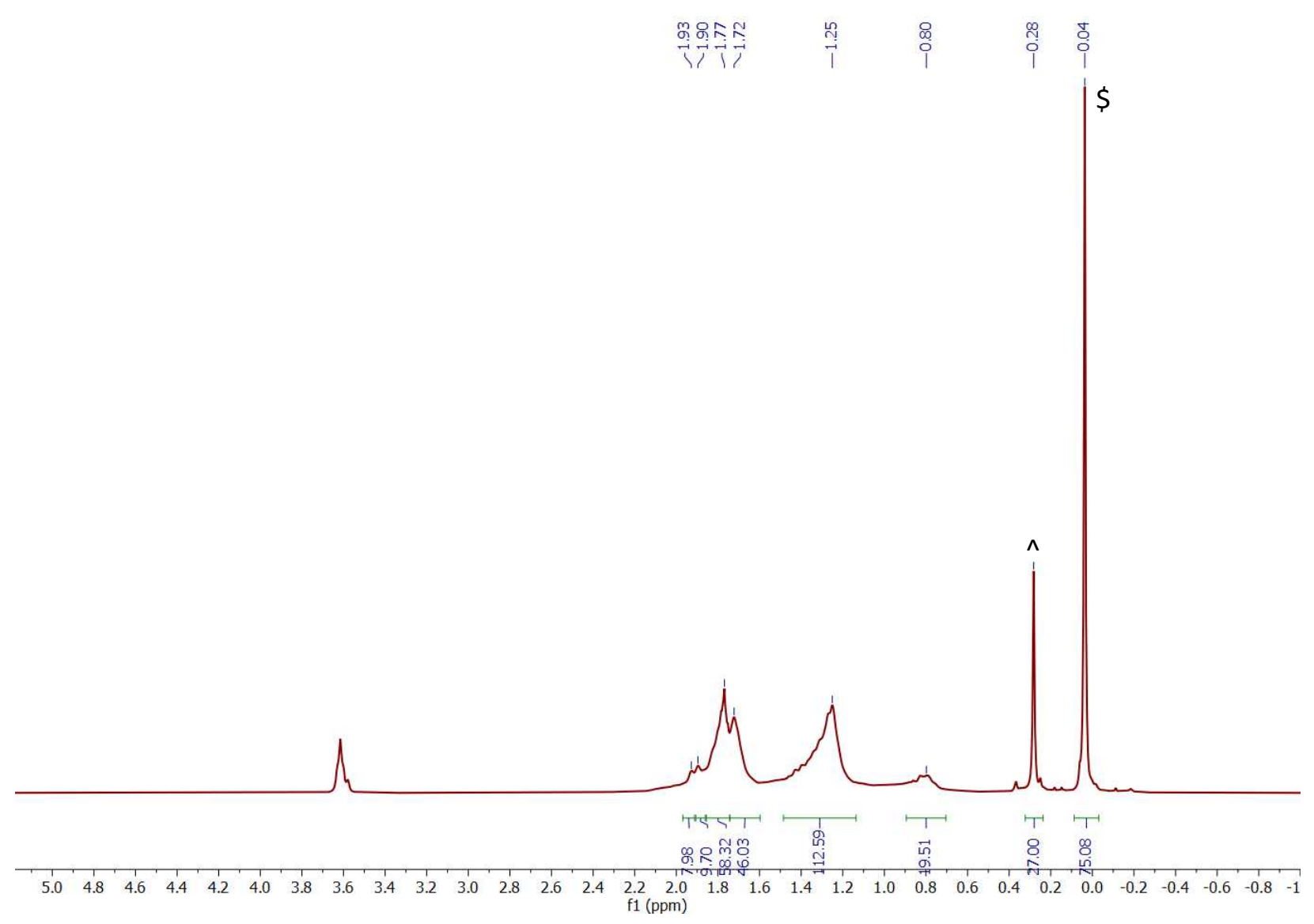

Figure S12. In situ ${ }^{1} \mathrm{H}$ NMR spectrum (in THF- $\left.d_{8}\right)$ of the reaction of $\left[\mathrm{UO}_{2}\left(\mathrm{~N}\left(\mathrm{SiMe}_{3}\right)_{2}\right)_{2}(\mathrm{THF})_{2}\right]$ and 1 equiv of $\mathrm{Cy}_{7} \mathrm{Si}_{7} \mathrm{O}_{9}(\mathrm{OH})_{3} .^{\wedge}$ indicates resonances assignable to $\mathbf{1}$, and $\$$ indicates resonances assignable to $\mathrm{HN}\left(\mathrm{SiMe}_{3}\right)_{2}$. Experimental Details: $\mathrm{Cy}_{7} \mathrm{Si}_{7} \mathrm{O}_{9}(\mathrm{OH})_{3}(119.1 \mathrm{mg}, 0.122 \mathrm{mmol})$ was dissolved in THF-d $d_{8}(0.75 \mathrm{~mL})$ to yield a colorless solution. The solution was transferred to an NMR tube equipped with a J-Young valve and its ${ }^{1} \mathrm{H}$ and ${ }^{29} \mathrm{Si}\left\{{ }^{1} \mathrm{H}\right\}$ NMR spectra were recorded. The tube was brought back into the glovebox, and an orange solution of $\left[\mathrm{UO}_{2}\left(\mathrm{~N}\left(\mathrm{SiMe}_{3}\right)_{2}\right)_{2}(\mathrm{THF})_{2}\right]$ $(88.3 \mathrm{mg}, 0.120 \mathrm{mmol})$ in THF- $d_{8}(0.5 \mathrm{~mL})$ was added. This addition resulted in an immediate color change to bright orange, concomitant with deposition of a small amount of fine yellow precipitate. The sample was then brought out of the glovebox and its ${ }^{1} \mathrm{H}$ and ${ }^{29} \mathrm{Si}\left\{{ }^{1} \mathrm{H}\right\}$ NMR spectra were recorded overnight. ${ }^{1} \mathrm{H}$ NMR $\left(\mathrm{THF}-d_{8}, 25^{\circ} \mathrm{C}, 400 \mathrm{MHz}\right): \delta 0.04$ (s, 18H, HN(SiMe $\left.)_{2}\right), 0.28$ (s, 27H, 1). ${ }^{29} \mathrm{Si}\left\{{ }^{1} \mathrm{H}\right\}$ NMR (THF-d8, $\left.25{ }^{\circ} \mathrm{C}, 79 \mathrm{MHz}\right): \delta-74.54(3 \mathrm{Si}, 3),-73.47$ (3Si, 1), -70.57 (8Si, $\left.\mathrm{Cy}_{8} \mathrm{Si}_{8} \mathrm{O}_{12}\right),-69.47$ (3Si, 1), -69.31 (3Si, 3), -68.57 (1Si, 1), -68.48 (1Si, 3), 1.44 (2Si, $\left.\mathrm{HN}\left(\mathrm{SiMe}_{3}\right)_{2}\right), 20.91$ (3Si, OSiMe 3,1$)$. The mixture was brought back into the glovebox, and was filtered through a pre-weighed $0.2 \mu \mathrm{m}$ PTFE membrane to yield an orange filtrate. A yellow powder remained inside the membrane, which was washed with THF $(4 \times 1 \mathrm{~mL})$ and weighed after standing at room temperature for $5 \mathrm{~d}(9.8 \mathrm{mg})$. An XPS spectrum of this solid was then collected, which revealed an approximately 1:2 uranium to silsesquioxane ratio (Figure S26). Using this ratio, along with the isolated mass, the yellow powder was calculated to account for $\sim 4 \%$ of the uranium in the reaction mixture. The volatiles were removed from the filtrate in vacuo, and the resulting orange solid was extracted into 2:1 $\mathrm{Et} 2 \mathrm{O} / \mathrm{MeCN}(2 \mathrm{~mL})$ and filtered through a Celite column supported on glass wool $(0.5 \mathrm{~cm} \times 2 \mathrm{~cm})$ to yield an orange filtrate. Storage of this 
solution at $-25{ }^{\circ} \mathrm{C}$ for $24 \mathrm{~h}$ resulted in deposition of orange plates of $\mathbf{1}$, which were isolated by decanting off the supernatant $(17.5 \mathrm{mg}, 10 \%$ yield $)$. 


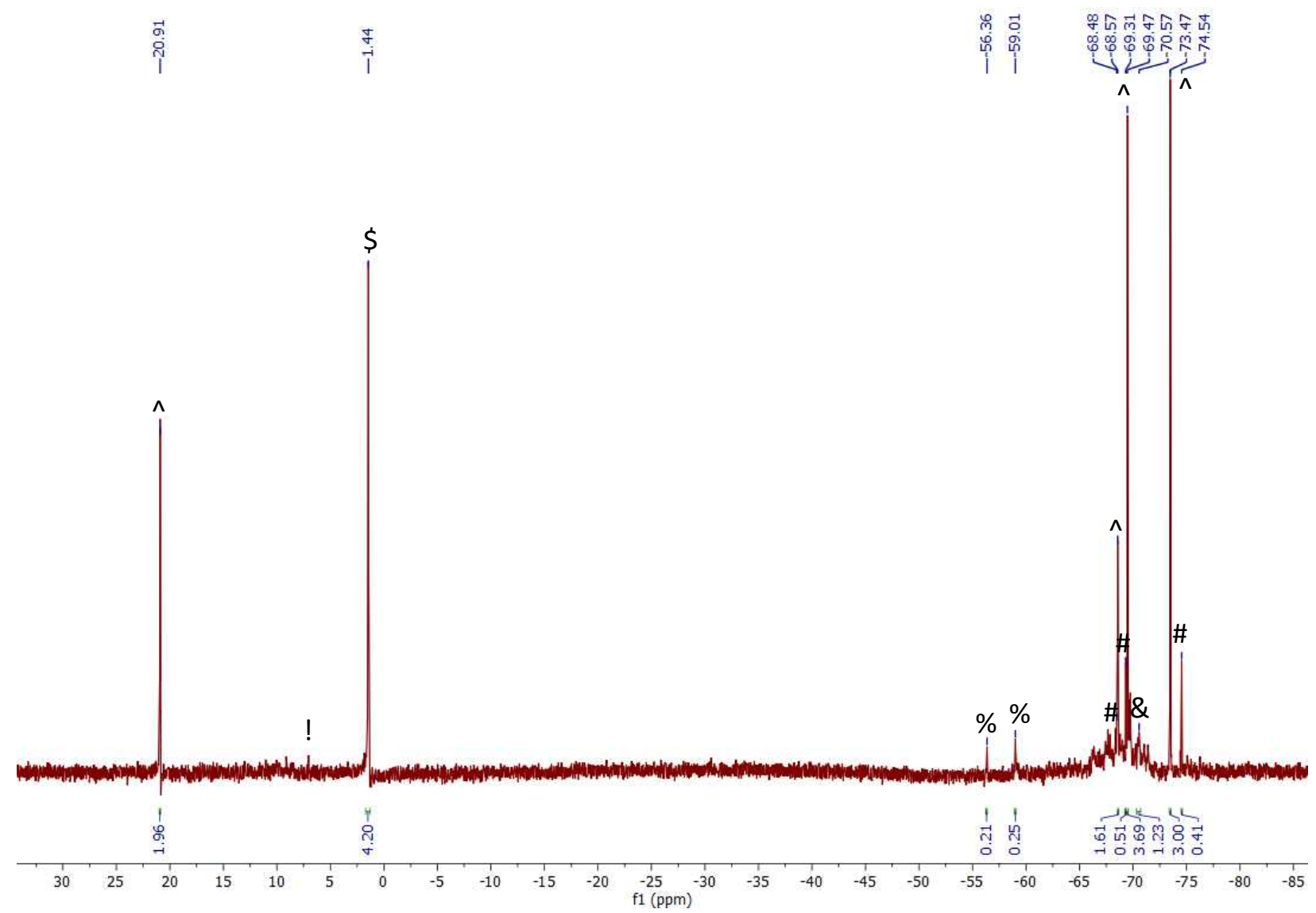

Figure S13. In situ ${ }^{29} \mathrm{Si}\left\{{ }^{1} \mathrm{H}\right\}$ NMR spectrum (in THF- $d_{8}$ ) of the reaction of $\left[\mathrm{UO}_{2}\left(\mathrm{~N}\left(\mathrm{SiMe}_{3}\right)_{2}\right)_{2}(\mathrm{THF})_{2}\right]$ and 1 equiv of $\mathrm{Cy}_{7} \mathrm{Si}_{7} \mathrm{O}_{9}(\mathrm{OH})_{3} .{ }^{\wedge}$ indicates resonances assignable to $\mathbf{1}$, \# indicates resonances assignable to $\mathbf{3}, \mathbf{\$}$ indicates resonances assignable to $\mathrm{HN}\left(\mathrm{SiMe}_{3}\right)_{2}, \boldsymbol{\&}$ indicates resonances assignable to $\mathrm{Cy}_{8} \mathrm{Si}_{8} \mathrm{O}_{12}{ }^{11}$ ! indicates resonances assignable to $\left(\mathrm{Me}_{3} \mathrm{Si}\right)_{2} \mathrm{O}$, and $\%$ indicates resonances assignable to unidentified ligand decomposition products.

Experimental Details: See details for Figure S12. 


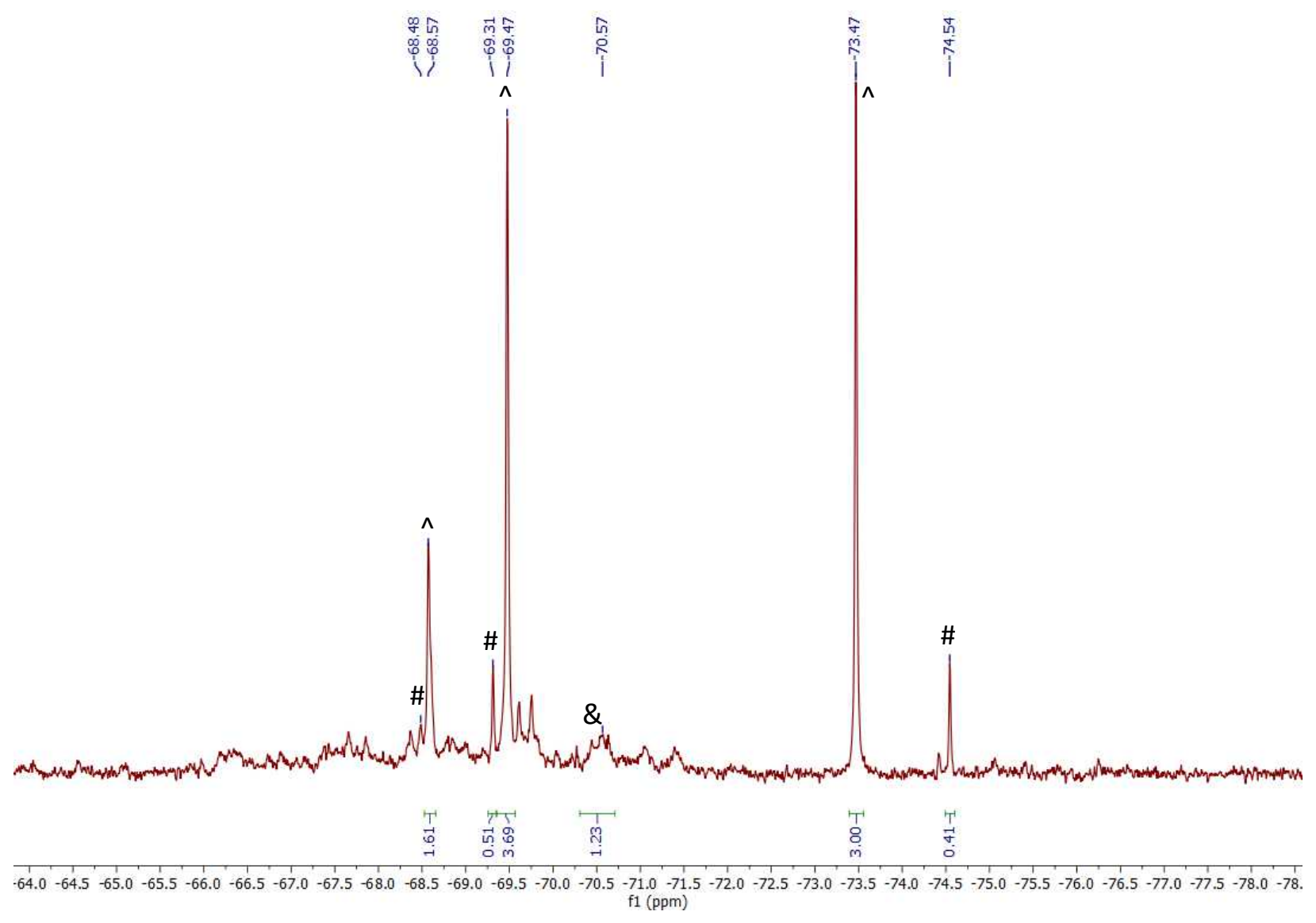

Figure S14. Partial ${ }^{29} \mathrm{Si}\left\{{ }^{1} \mathrm{H}\right\}$ NMR spectrum (in THF- $\left.d_{8}\right)$ of the reaction of $\left[\mathrm{UO}_{2}\left(\mathrm{~N}\left(\mathrm{SiMe}_{3}\right)_{2}\right)_{2}(\mathrm{THF})_{2}\right]$ and 1 equiv of $\mathrm{Cy}_{7} \mathrm{Si}_{7} \mathrm{O}_{9}(\mathrm{OH})_{3} .{ }^{\wedge}$ indicates resonances assignable to $\mathbf{1}$, \# indicates resonances assignable to $\mathbf{3}$, and $\&$ indicates resonances assignable to $\mathrm{Cy}_{8} \mathrm{Si}_{8} \mathrm{O}_{12 .}{ }^{11}$ Experimental Details: See details for Figure S12. 

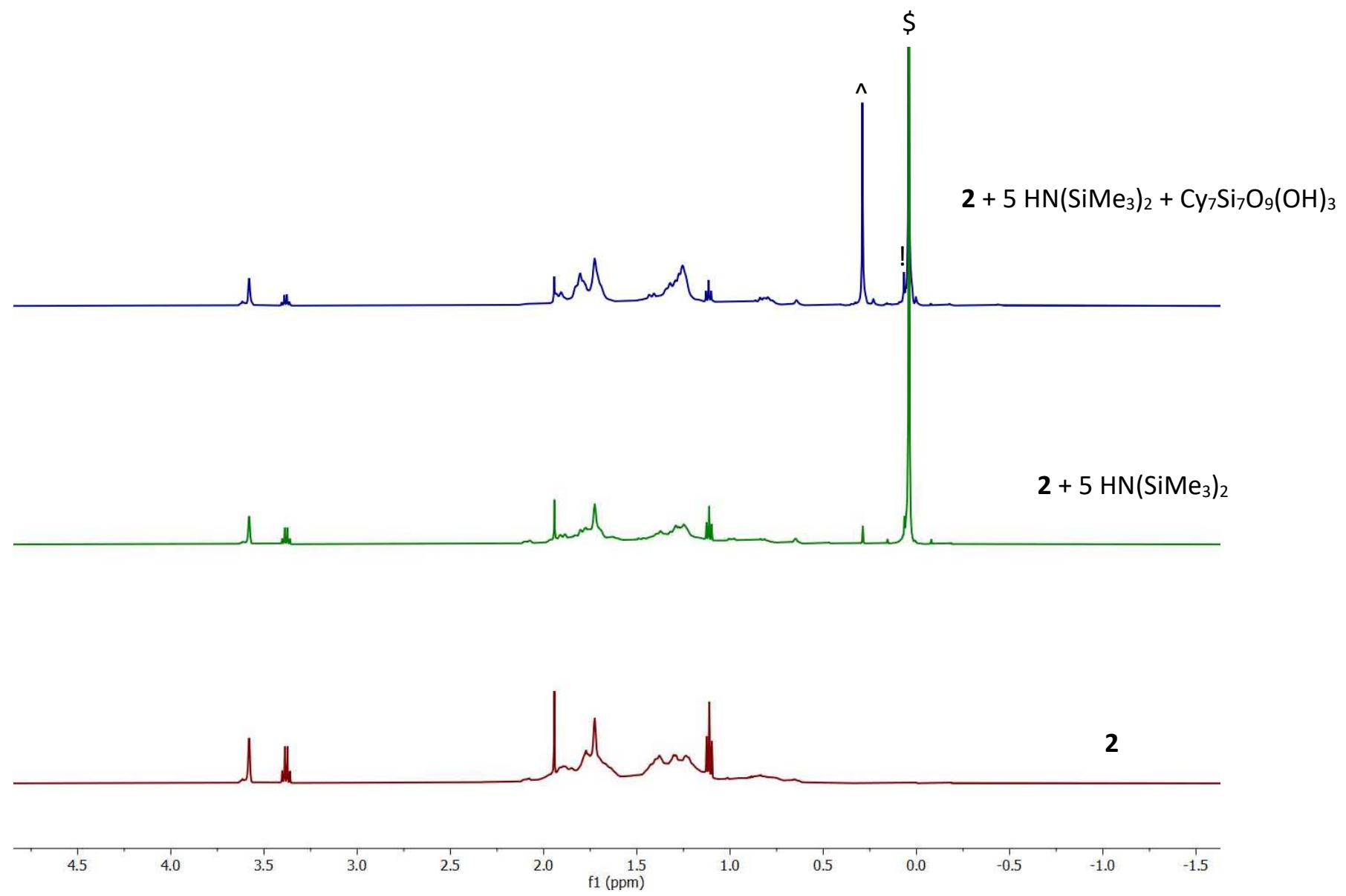

Figure S15. In situ ${ }^{1} \mathrm{H}$ NMR spectrum (in THF-d8) of the reaction of $\left[\left(\mathrm{UO}_{2}\right)_{3}\left(\mathrm{Cy}_{7} \mathrm{Si}_{7} \mathrm{O}_{12}\right)_{2}(\mathrm{MeCN})_{2}\left(\mathrm{Et}_{2} \mathrm{O}\right)\right]$ (2) with 5 equiv of $\mathrm{HN}\left(\mathrm{SiMe}_{3}\right)_{2}$ followed by 1 equiv of $\mathrm{Cy}_{7} \mathrm{Si}_{7} \mathrm{O}_{9}(\mathrm{OH})_{3} . \wedge$ indicates resonances assignable to $1, \$$ indicates resonances assignable to $\mathrm{HN}\left(\mathrm{SiMe}_{3}\right)_{2}$, and ! indicates resonances assignable to $\left(\mathrm{Me}_{3} \mathrm{Si}\right)_{2} \mathrm{O}$. Experimental Details: Crystals of 2 (38.8 mg, $0.013 \mathrm{mmol}$ ) were dissolved in $0.75 \mathrm{~mL}$ of THF-d8 to yield a yellow solution. The solution was transferred to an NMR tube equipped with a J-Young valve and its ${ }^{1} \mathrm{H}$ and ${ }^{29} \mathrm{Si}\left\{{ }^{1} \mathrm{H}\right\}$ NMR spectra were recorded. The tube was brought back into the glovebox, and a colorless solution of $\mathrm{HN}\left(\mathrm{SiMe}_{3}\right)_{2}(14 \mu \mathrm{L}, 0.067 \mathrm{mmol}, 5$ equiv) was added. The resulting solution was allowed to stand at room temperature for $30 \mathrm{~min}$, whereupon a small amount of yellow precipitate formed. ${ }^{1} \mathrm{H}$ and ${ }^{29} \mathrm{Si}\left\{{ }^{1} \mathrm{H}\right\}$ NMR spectra of the resulting mixture were then recorded. ${ }^{1} \mathrm{H}$ NMR (THF- $\left.d_{8}, 25{ }^{\circ} \mathrm{C}, 500 \mathrm{MHz}\right): \delta 0.04$ (s, 18H, HN(SiMe $\left.)_{2}\right), 0.07$ (s, 18H, $\left.(\mathrm{Me} 3 \mathrm{Si})_{2} \mathrm{O}\right), 0.29$ (s, 27H, 1). ${ }^{29} \mathrm{Si}\left\{{ }^{1} \mathrm{H}\right\} \mathrm{NMR}$ (THF-d8, $\left.25{ }^{\circ} \mathrm{C}, 99 \mathrm{MHz}\right): \delta-74.54(3 \mathrm{Si}, 3),-73.47$ (3Si, 1), -72.12 (2), -70.98 (8Si, $\mathrm{Cy}_{8} \mathrm{Si}_{8} \mathrm{O}_{12}$ ), -70.17 (2), -69.46 (3Si, 1), -69.29 (overlapping peaks for 2 and 3), -68.56 (1Si, 1), -68.46 (1Si, 3), -68.07 (2), -67.79 (2), 1.45 (2Si, $\left.\mathrm{HN}\left(\mathrm{SiMe}_{3}\right)_{2}\right), 7.06\left(2 \mathrm{Si},\left(\mathrm{Me} \mathrm{Si}_{2} \mathrm{O}\right), 20.93\right.$ (3Si, $\left.\mathrm{OSiMe}_{3}, 1\right)$. The sample was brought back into the glove box and $\mathrm{Cy}_{7} \mathrm{Si}_{7} \mathrm{O}_{9}(\mathrm{OH})_{3}(13.8 \mathrm{mg}, 0.014 \mathrm{mmol}, 1$ equiv) was added as a solid. This addition resulted in an immediate color change to orange, concomitant with deposition of more fine yellow precipitate. The resulting mixture was allowed to stand at room temperature for 30 min, whereupon its ${ }^{1} \mathrm{H}$ and ${ }^{29} \mathrm{Si}\left\{{ }^{1} \mathrm{H}\right\}$ NMR spectra were re-recorded. ${ }^{1} \mathrm{H}$ NMR (THF-d8, $25{ }^{\circ} \mathrm{C}$, $500 \mathrm{MHz}): \delta 0.04$ (s, 18H, HN( $\left.\left.\mathrm{SiMe}_{3}\right)_{2}\right), 0.07$ (s, 18H, (Me $\left.\left.3 \mathrm{Si}\right)_{2} \mathrm{O}\right), 0.29(\mathrm{~s}, 27 \mathrm{H}, 1) .{ }^{29} \mathrm{Si}\left\{{ }^{1} \mathrm{H}\right\}$ NMR (THF- $\left.d_{8}, 25{ }^{\circ} \mathrm{C}, 99 \mathrm{MHz}\right): \delta-74.54(3 \mathrm{Si}, 3),-73.47(3 \mathrm{Si}, 1),-70.99\left(8 \mathrm{Si}, \mathrm{Cy}_{8} \mathrm{Si}_{8} \mathrm{O}_{12}\right)$, - 
69.46 (3Si, 1), -69.30 (3Si, 3), -68.56 (1Si, 1), -68.46 (1Si, 3), 1.45 (2Si, HN( $\left.\left.\mathrm{SiMe}_{3}\right) 2\right), 7.06$ (2Si, $\left.\left(\mathrm{Me}_{3} \mathrm{Si}\right)_{2} \mathrm{O}\right), 20.93\left(3 \mathrm{Si}, \mathrm{OSiMe}_{3}, 1\right)$. 


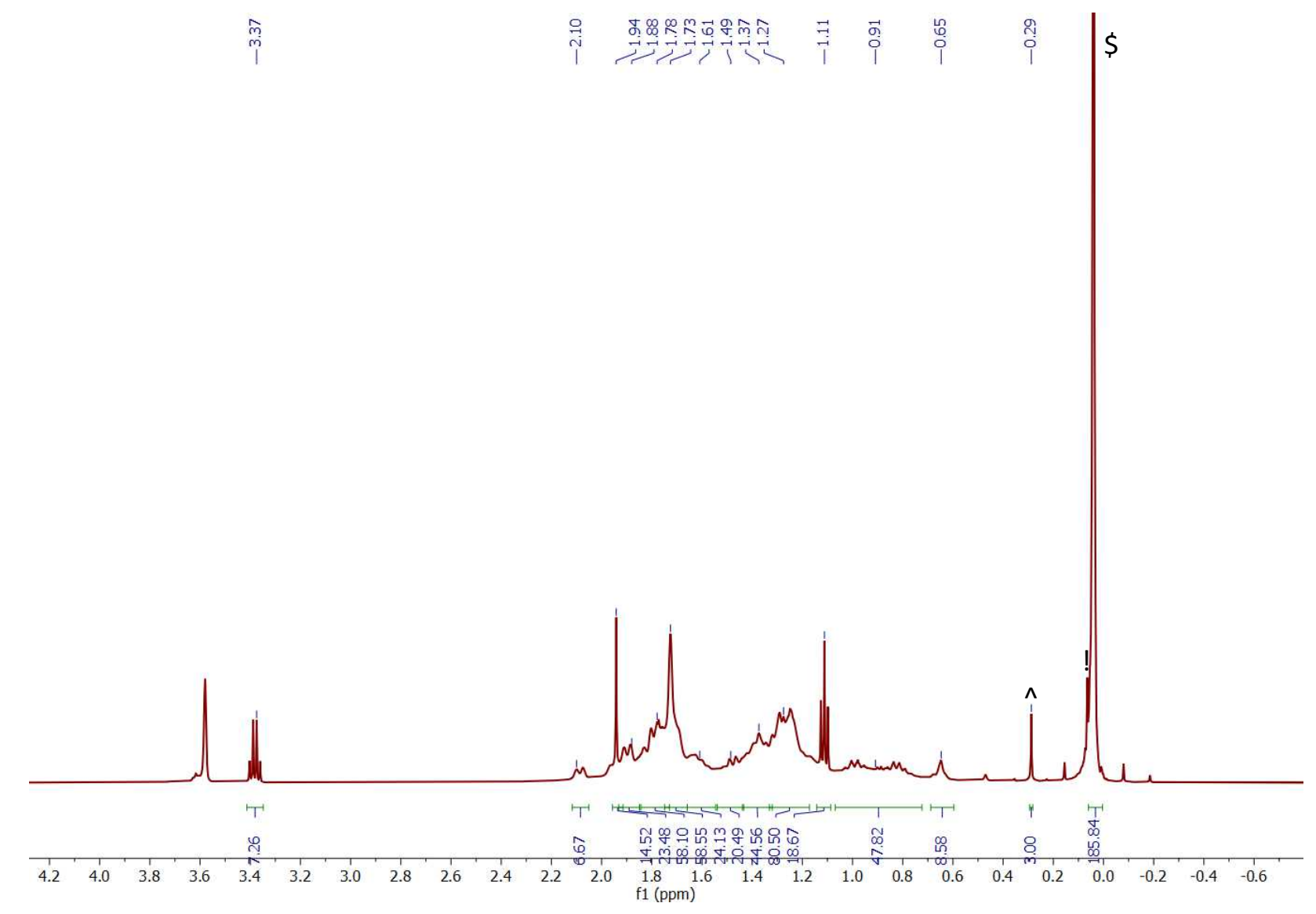

Figure S16. In situ ${ }^{1} \mathrm{H}$ NMR spectrum (in THF-d8) of a mixture of $\left[\left(\mathrm{UO}_{2}\right)_{3}\left(\mathrm{Cy}_{7} \mathrm{Si}_{7} \mathrm{O}_{12}\right)_{2}(\mathrm{MeCN})_{2}\left(\mathrm{Et}_{2} \mathrm{O}\right)\right](2)$ and 5 equiv of $\mathrm{HN}\left(\mathrm{SiMe}_{3}\right)_{2 .}{ }^{\wedge}$ indicates resonances assignable to $1, \$$ indicates resonances assignable to $\mathrm{HN}\left(\mathrm{SiMe}_{3}\right)_{2}$, and ! indicates resonances assignable to $\left(\mathrm{Me}_{3} \mathrm{Si}\right)_{2} \mathrm{O}$. Experimental Details: See figure caption for Figure $\mathrm{S} 15$. 


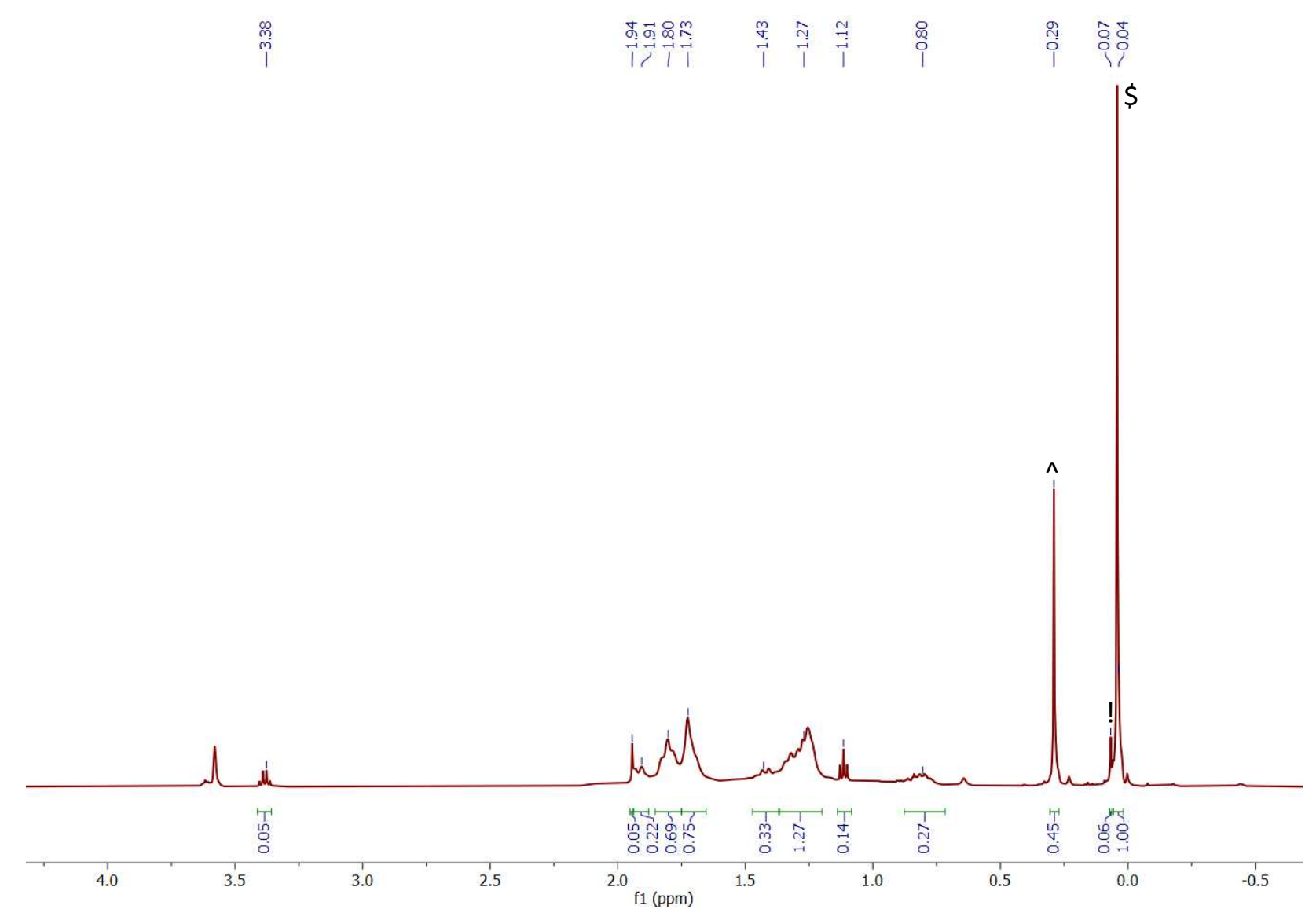

Figure S17. In situ ${ }^{1} \mathrm{H}$ NMR spectrum (in THF-d8) of a mixture of $\left[\left(\mathrm{UO}_{2}\right)_{3}\left(\mathrm{Cy}_{7} \mathrm{Si}_{7} \mathrm{O}_{12}\right)_{2}(\mathrm{MeCN})_{2}\left(\mathrm{Et}_{2} \mathrm{O}\right)\right](2), 5$ equiv of $\mathrm{HN}\left(\mathrm{SiMe}_{3}\right)_{2}$ and 1 equiv of $\mathrm{Cy}_{7} \mathrm{Si}_{7} \mathrm{O}_{9}(\mathrm{OH})_{3}$. $\wedge$ indicates resonances assignable to $\mathbf{1}, \$$ indicates resonances assignable to $\mathrm{HN}\left(\mathrm{SiMe}_{3}\right)_{2}$, and ! indicates resonances assignable to $\left(\mathrm{Me}_{3} \mathrm{Si}\right)_{2} \mathrm{O}$. Experimental Details: See figure caption for Figure S15. 


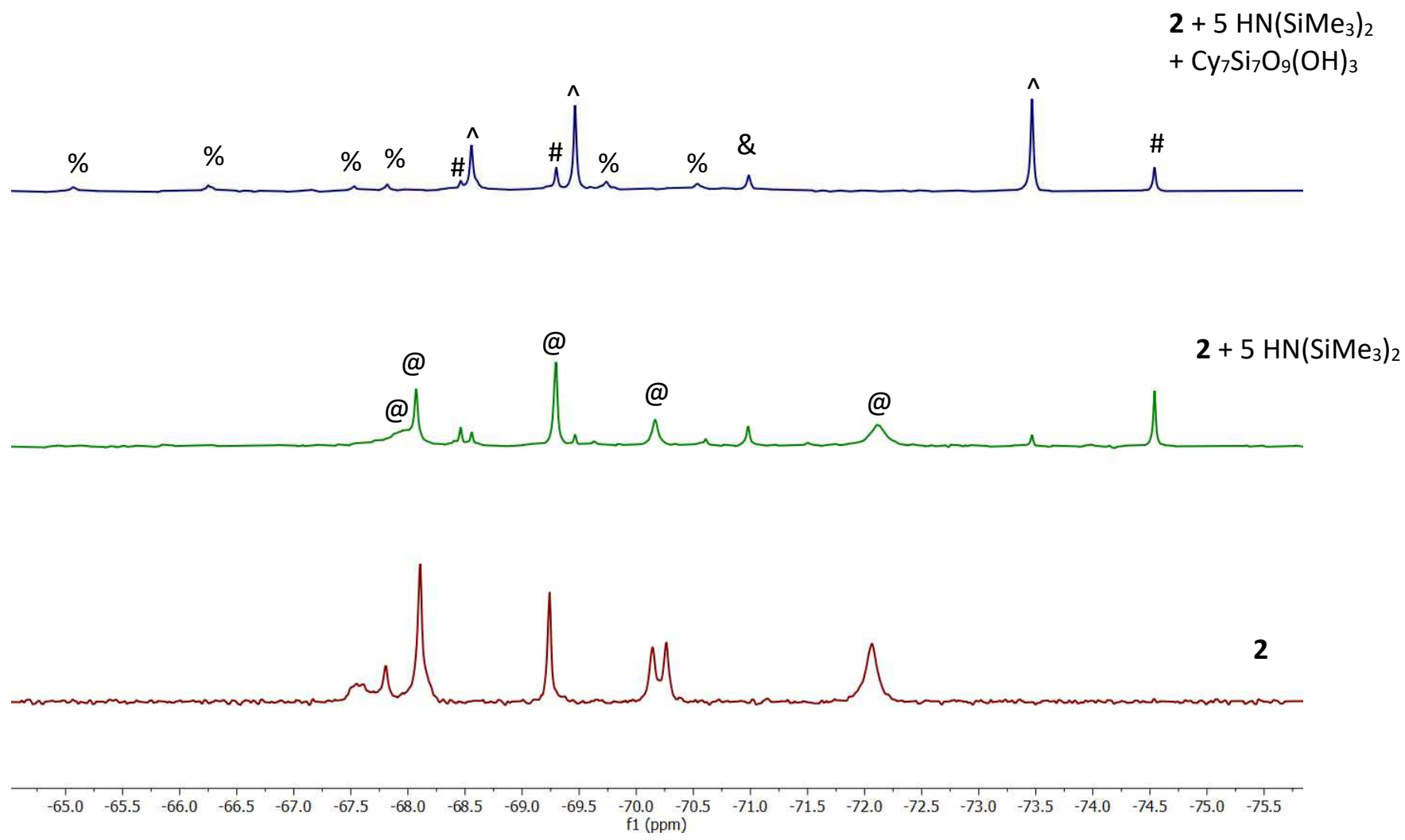

Figure S18. In situ ${ }^{29} \mathrm{Si}\left\{{ }^{1} \mathrm{H}\right\}$ NMR spectrum (in THF- $d_{8}$ ) of the reaction of $\left[\left(\mathrm{UO}_{2}\right)_{3}\left(\mathrm{Cy}_{7} \mathrm{Si}_{7} \mathrm{O}_{12}\right)_{2}(\mathrm{MeCN})_{2}\left(\mathrm{Et}_{2} \mathrm{O}\right)\right]$ (2) with 5 equiv of $\mathrm{HN}\left(\mathrm{SiMe}_{3}\right)_{2}$ followed by 1 equiv of $\mathrm{Cy}_{7} \mathrm{Si}_{7} \mathrm{O}_{9}(\mathrm{OH})_{3} . \wedge$ indicates resonances assignable to 1, @ indicates resonances assignable to 2, \# indicates resonances assignable to $\mathbf{3}, \mathbf{\&}$ indicates resonances assignable to $\mathrm{Cy}_{8} \mathrm{Si}_{8} \mathrm{O}_{12},{ }^{11}$ and \% indicates resonances assignable to unidentified products. Experimental Details: See figure caption for Figure S15. 


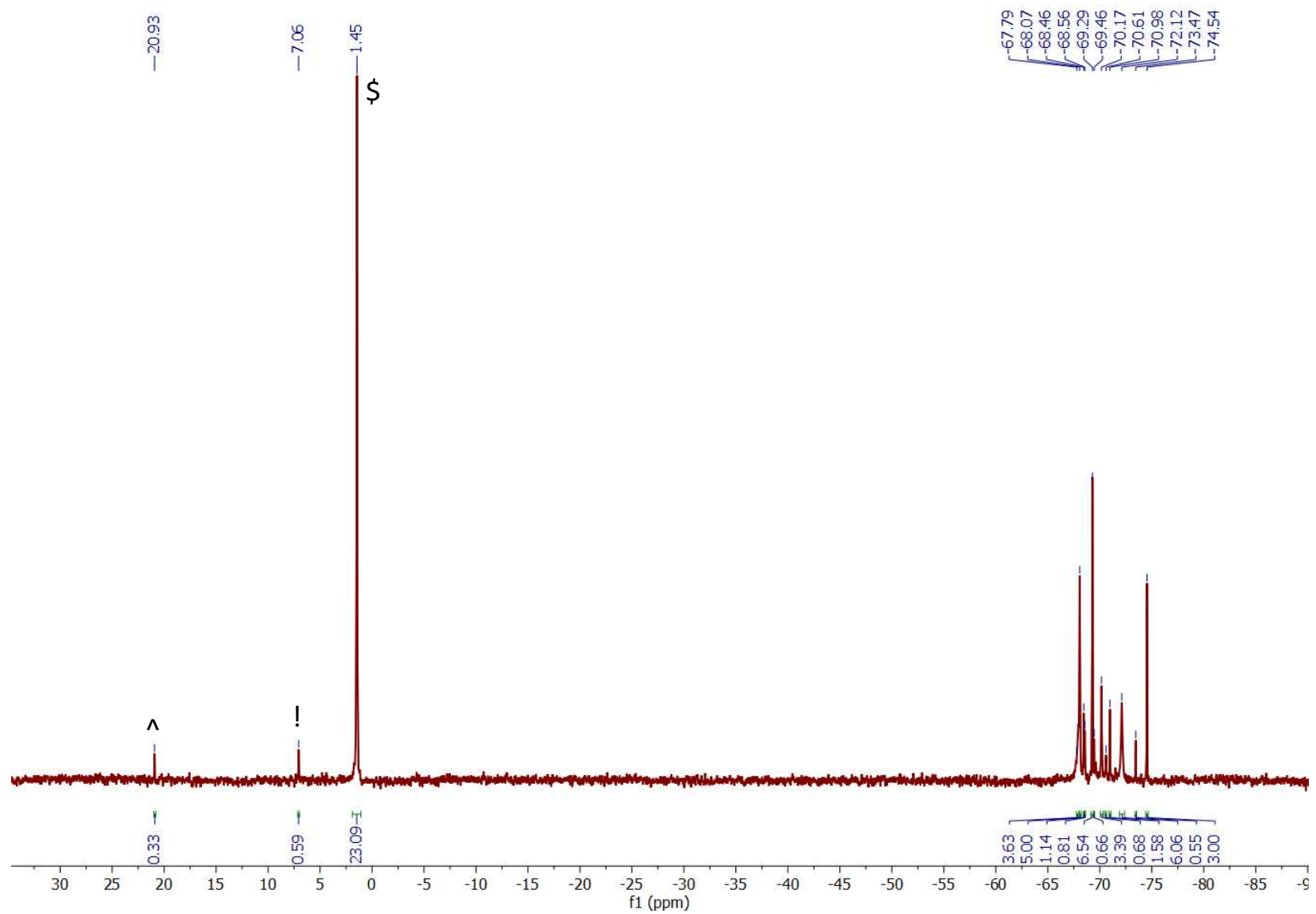

Figure S19. In situ ${ }^{29} \mathrm{Si}\left\{{ }^{1} \mathrm{H}\right\}$ NMR spectrum (in THF- $d_{8}$ ) of a mixture of $\left[\left(\mathrm{UO}_{2}\right)_{3}\left(\mathrm{Cy}_{7} \mathrm{Si}_{7} \mathrm{O}_{12}\right)_{2}(\mathrm{MeCN})_{2}\left(\mathrm{Et}_{2} \mathrm{O}\right)\right](2)$ and 5 equiv of $\mathrm{HN}\left(\mathrm{SiMe}_{3}\right) .{ }^{\wedge}$ indicates resonances assignable to $1, \$$ indicates resonances assignable to $\mathrm{HN}\left(\mathrm{SiMe}_{3}\right)_{2}$, and ! indicates resonances assignable to $\left(\mathrm{Me}_{3} \mathrm{Si}\right)_{2} \mathrm{O}$. Experimental Details: See figure caption for Figure $\mathrm{S} 15$. 


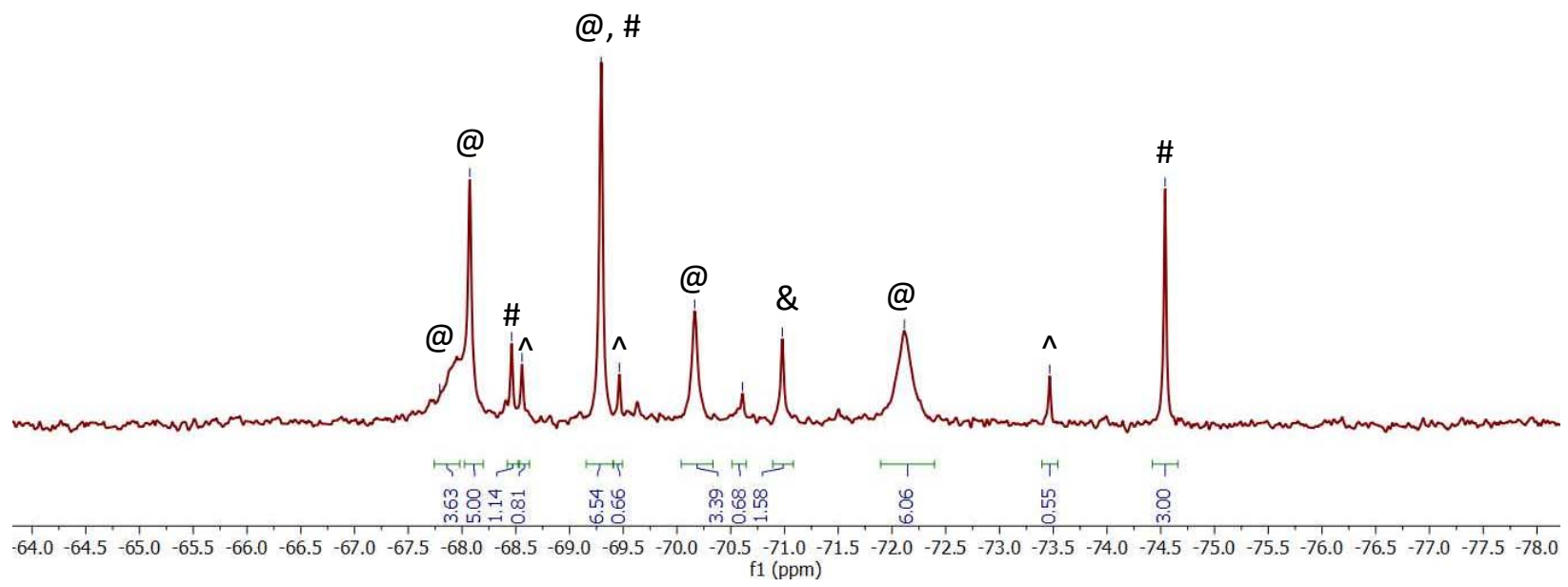

Figure S20. Partial in situ ${ }^{29} \mathrm{Si}\left\{{ }^{1} \mathrm{H}\right\}$ NMR spectrum (in THF- $d_{8}$ ) of a mixture of $\left[\left(\mathrm{UO}_{2}\right)_{3}\left(\mathrm{Cy}_{7} \mathrm{Si}_{7} \mathrm{O}_{12}\right)_{2}(\mathrm{MeCN})_{2}\left(\mathrm{Et}_{2} \mathrm{O}\right)\right](2)$ and 5 equiv of $\mathrm{HN}\left(\mathrm{SiMe}_{3}\right)_{2 .}{ }^{\wedge}$ indicates resonances assignable to 1, @ indicates resonances assignable to 2,\# indicates resonances assignable to 3, and $\&$ indicates resonances assignable to $\mathrm{Cy}_{8} \mathrm{Si}_{8} \mathrm{O}_{12}{ }^{11}$ Experimental Details: See figure caption for Figure S15. 


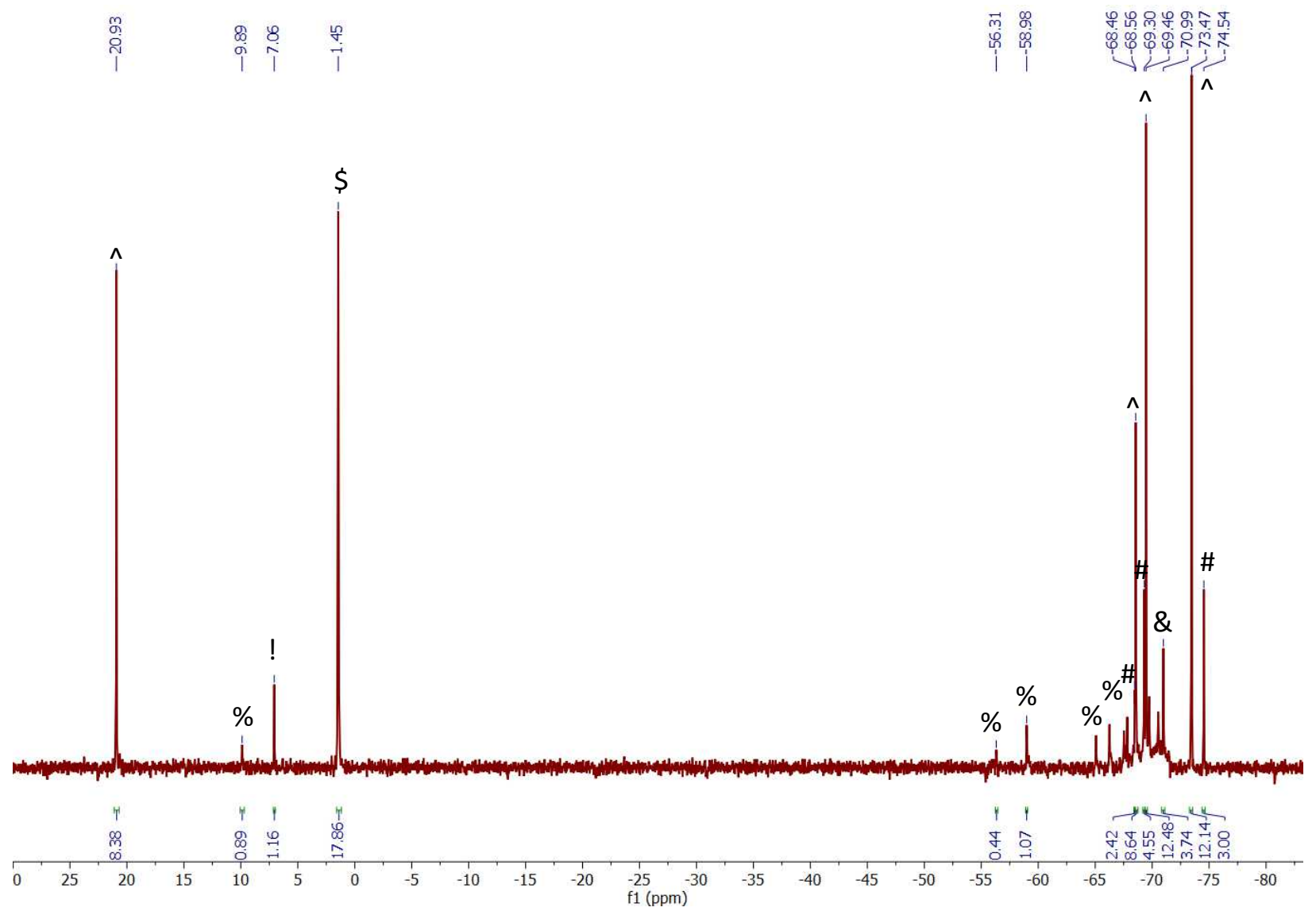

Figure S21. In situ ${ }^{29} \mathrm{Si}\left\{{ }^{1} \mathrm{H}\right\}$ NMR spectrum (in THF- $d_{8}$ ) of a mixture of $\left[\left(\mathrm{UO}_{2}\right)_{3}\left(\mathrm{Cy}_{7} \mathrm{Si}_{7} \mathrm{O}_{12}\right)_{2}(\mathrm{MeCN})_{2}\left(\mathrm{Et}_{2} \mathrm{O}\right)\right](2), 5$ equiv of $\mathrm{HN}\left(\mathrm{SiMe}_{3}\right)_{2}$ and 1 equiv of $\mathrm{Cy}_{7} \mathrm{Si}_{7} \mathrm{O}_{9}(\mathrm{OH})_{3}$. $\wedge$ indicates resonances assignable to $\mathbf{1}$, \# indicates resonances assignable to $\mathbf{3}, \mathbf{\$}$ indicates resonances assignable to $\mathrm{HN}\left(\mathrm{SiMe}_{3}\right)_{2}$, \& indicates resonances assignable to $\mathrm{Cy}_{8} \mathrm{Si}_{8} \mathrm{O}_{12},{ }^{11}$ ! indicates resonances assignable to $(\mathrm{Me} 3 \mathrm{Si})_{2} \mathrm{O}, \%$ indicates resonances assignable to unidentified minor by-products. Experimental Details: See figure caption for Figure S15. 


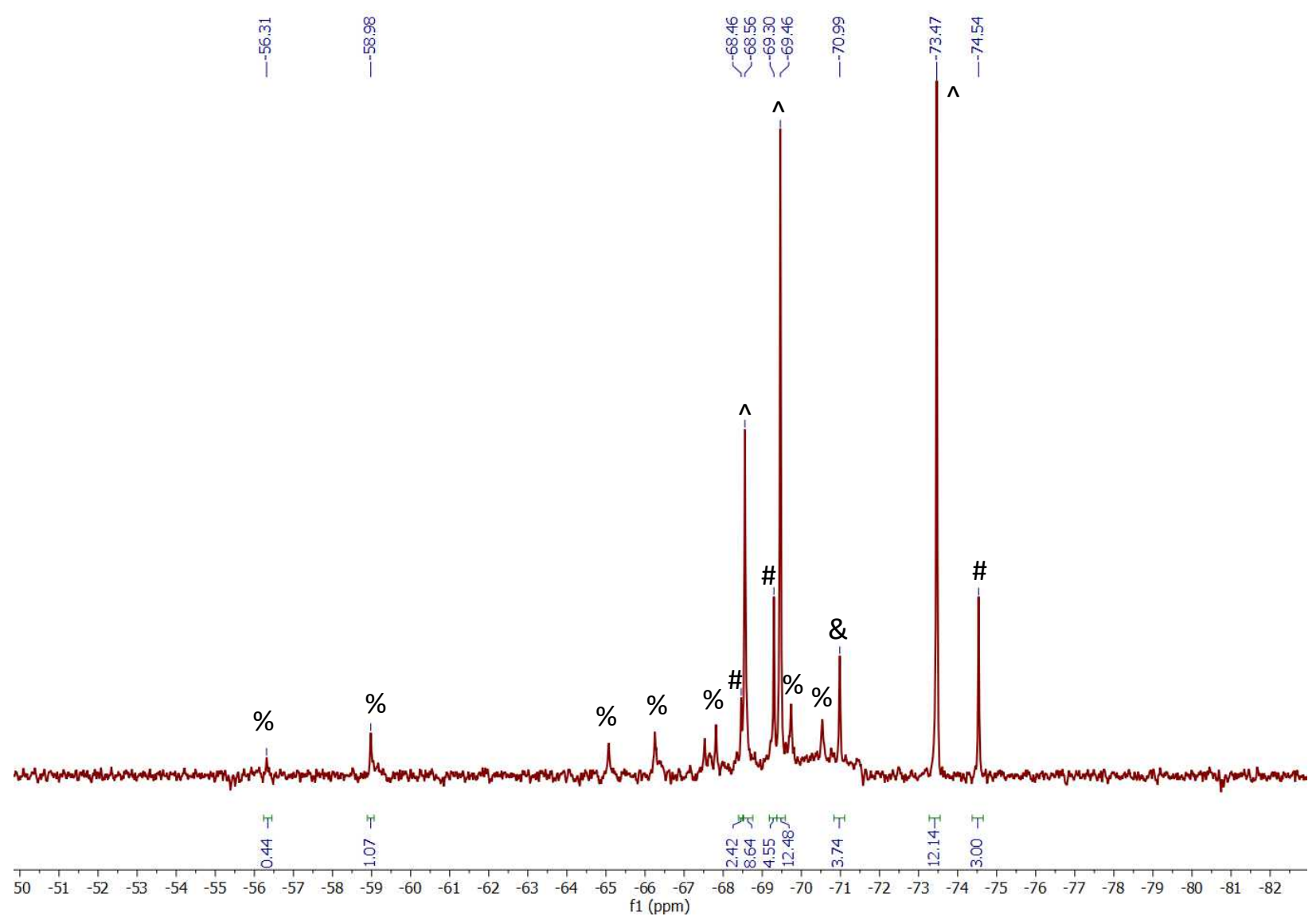

Figure S22. In situ ${ }^{29} \mathrm{Si}\left\{{ }^{1} \mathrm{H}\right\}$ NMR spectrum (in THF- $d_{8}$ ) of a mixture of $\left[\left(\mathrm{UO}_{2}\right)_{3}\left(\mathrm{Cy}_{7} \mathrm{Si}_{7} \mathrm{O}_{12}\right)_{2}(\mathrm{MeCN})_{2}\left(\mathrm{Et}_{2} \mathrm{O}\right)\right](2), 5$ equiv of $\mathrm{HN}\left(\mathrm{SiMe}_{3}\right)_{2}$ and 1 equiv of $\mathrm{Cy}_{7} \mathrm{Si}_{7} \mathrm{O}_{9}(\mathrm{OH})_{3}$. $\wedge$ indicates resonances assignable to $\mathbf{1}$, \# indicates resonances assignable to $\mathbf{3}, \boldsymbol{\&}$ indicates resonances assignable to $\mathrm{Cy}_{8} \mathrm{Si}_{8} \mathrm{O}_{12},{ }^{11}$ and \% indicates resonances assignable to unidentified minor by-products. Experimental Details: See figure caption for Figure S15. 


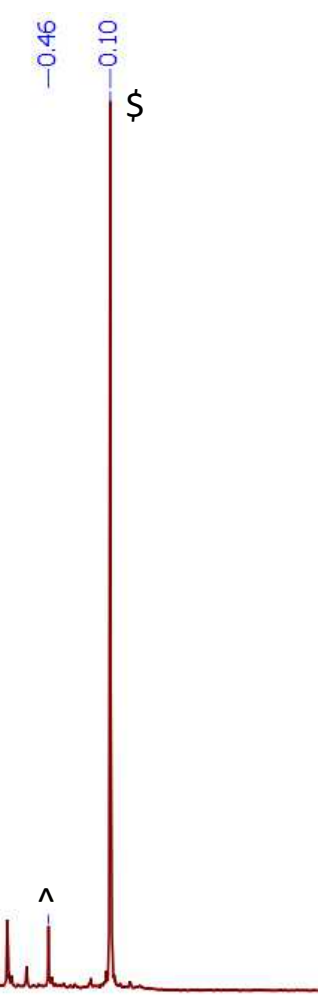

\begin{tabular}{rrrrrrrrrrrrrrrrrrr}
1 & 1 \\
\hline 8.0 & 7.5 & 7.0 & 6.5 & 6.0 & 5.5 & 5.0 & 4.5 & 4.0 & $\begin{array}{r}1 \\
1.5\end{array}$ & 3.0 & 2.5 & 2.0 & 1.5 & 1.0 & 0.5 & 0.0 & -0.5 & -1.0
\end{tabular}

Figure S23. ${ }^{1} \mathrm{H}$ NMR spectrum (in $\mathrm{C}_{6} \mathrm{D}_{6}$ ) of an aliquot of the reaction between $\left[\mathrm{UO}_{2}\left(\mathrm{~N}\left(\mathrm{SiMe}_{3}\right)_{2}\right)_{2}(\mathrm{THF})_{2}\right]$ and 1 equiv of $\mathrm{Cy}_{7} \mathrm{Si}_{7} \mathrm{O}_{9}(\mathrm{OH})_{3}$ in hexanes. ${ }^{\wedge}$ indicates resonances assignable to 1, and \$ indicates resonances assignable to $\mathrm{HN}\left(\mathrm{SiMe}_{3}\right)_{2}$. Experimental Details: To a stirring orange solution of $\left[\mathrm{UO}_{2}\left(\mathrm{~N}\left(\mathrm{SiMe}_{3}\right)_{2}\right)_{2}(\mathrm{THF})_{2}\right](30.2 \mathrm{mg}, 0.041 \mathrm{mmol})$ in hexanes $(1 \mathrm{~mL})$ was added dropwise, very slowly, a slurry of $\mathrm{Cy}_{7} \mathrm{Si}_{7} \mathrm{O}_{9}(\mathrm{OH})_{3}(40.1 \mathrm{mg}, 0.041 \mathrm{mmol})$ in hexanes $(1 \mathrm{~mL})$. This addition resulted in an immediate color change to dark brown, and then gradually to yellow-orange. The mixture was allowed to stir at room temperature for $15 \mathrm{~min}$, whereupon the solution was filtered through a Celite column supported on glass wool $(0.5 \mathrm{~cm} \times 2 \mathrm{~cm})$ to yield a yellow-orange filtrate. An aliquot of the reaction mixture was then dried in vacuo. The resulting yellow solid was dissolved in $\mathrm{C}_{6} \mathrm{D}_{6}(0.75 \mathrm{ml})$ and a ${ }^{1} \mathrm{H}$ NMR spectrum was recorded. 
Table S1. Crystallographic details for complexes 1 and 2.

\begin{tabular}{|c|c|c|}
\hline & $1 \cdot 0.5 \mathrm{C}_{5} \mathrm{H}_{12}$ & $2 \cdot 3 \mathrm{MeCN} \cdot \mathrm{Et}_{2} \mathrm{O}$ \\
\hline Formula & $\mathrm{C}_{53.50} \mathrm{H}_{110} \mathrm{O}_{15} \mathrm{Si}_{10} \mathrm{U}$ & $\mathrm{C}_{102} \mathrm{H}_{189} \mathrm{~N}_{5} \mathrm{O}_{32} \mathrm{Si}_{14} \mathrm{U}_{3}$ \\
\hline Crystal Habit, Color & Plate, Orange & Rod, Yellow \\
\hline Crystal Size (mm) & $0.2 \times 0.1 \times 0.05$ & $0.25 \times 0.15 \times 0.1$ \\
\hline $\mathrm{MW}(\mathrm{g} / \mathrm{mol})$ & 1512.34 & 3104.92 \\
\hline crystal system & Monoclinic & Monoclinic \\
\hline space group & $\mathrm{P} 2 / \mathrm{c}$ & $\mathrm{P} 2{ }_{1} / \mathrm{c}$ \\
\hline $\mathrm{a}(\AA)$ & $25.785(3)$ & $19.266(4)$ \\
\hline $\mathrm{b}(\AA)$ & $13.9805(17)$ & $31.423(6)$ \\
\hline c $(\AA)$ & $20.860(3)$ & $24.877(5)$ \\
\hline$\alpha\left(^{\circ}\right)$ & 90 & 90.00 \\
\hline$\beta\left(^{\circ}\right)$ & $106.277(3)$ & $92.053(3)$ \\
\hline$\gamma\left({ }^{\circ}\right)$ & 90 & 90.00 \\
\hline $\mathrm{V}\left(\AA^{3}\right)$ & $7218.2(16)$ & $15051(5)$ \\
\hline Z & 4 & 4 \\
\hline $\mathrm{T}(\mathrm{K})$ & $100(2)$ & $100(2)$ \\
\hline$\lambda(\AA)$ & 0.71073 & 0.71073 \\
\hline GOF & 1.020 & 1.009 \\
\hline Density (calcd) $\left(\mathrm{Mg} / \mathrm{m}^{3}\right)$ & 1.392 & 1.370 \\
\hline $\begin{array}{l}\text { Absorption coefficient } \\
\left(\mathrm{mm}^{-1}\right)\end{array}$ & 2.470 & 3.393 \\
\hline $\mathrm{F}_{000}$ & 3132 & 6256 \\
\hline Total no Reflections & 33272 & 55747 \\
\hline Unique Reflections & 15835 & 25090 \\
\hline Final R indices* & $\begin{array}{l}\mathrm{R}_{1}=0.0785 \\
\mathrm{wR}_{2}=0.1681\end{array}$ & $\begin{array}{l}\mathrm{R}_{1}=0.0943 \\
\mathrm{wR}_{2}=0.2271\end{array}$ \\
\hline $\begin{array}{l}\text { Largest Diff. peak and hole } \\
\left(\mathrm{e}^{-} \mathrm{A}^{-3}\right)\end{array}$ & $3.066,-2.405$ & $3.010,-2.911$ \\
\hline
\end{tabular}


Table S2. Crystallographic details for complexes 3-5.

\begin{tabular}{|c|c|c|c|}
\hline & $4 \cdot 4 \mathrm{THF}$ & $5 \cdot 0.5 \mathrm{CH}_{2} \mathrm{Cl}_{2}$ & 3 \\
\hline Formula & $\mathrm{C}_{116} \mathrm{H}_{218} \mathrm{Li}_{2} \mathrm{O}_{32} \mathrm{Si}_{14} \mathrm{U}$ & $\mathrm{C}_{92.5} \mathrm{H}_{171} \mathrm{ClLiO}_{26} \mathrm{Si}_{14} \mathrm{U}$ & $\mathrm{C}_{84} \mathrm{H}_{154} \mathrm{O}_{24} \mathrm{Si}_{14} \mathrm{U}$ \\
\hline Crystal Habit, Color & Plate, Pink & Plate, Colorless & Plate, Yellow \\
\hline Crystal Size (mm) & $0.2 \times 0.15 \times 0.1$ & $0.15 \times 0.15 \times 0.1$ & $0.2 \times 0.15 \times 0.1$ \\
\hline $\mathrm{MW}(\mathrm{g} / \mathrm{mol})$ & 2770.06 & 2372.96 & 2179.35 \\
\hline crystal system & Monoclinic & Triclinic & Orthorhombic \\
\hline space group & $\mathrm{P} 2_{1} / \mathrm{c}$ & P -1 & Cmca \\
\hline $\mathrm{a}(\AA)$ & $18.8172(11)$ & $14.417(4)$ & $18.9919(14)$ \\
\hline $\mathrm{b}(\AA)$ & $28.943(2)$ & $15.026(4)$ & $25.2308(18)$ \\
\hline c $(\AA)$ & $26.8419(16)$ & $30.501(9)$ & $21.8579(16)$ \\
\hline$\alpha\left(^{\circ}\right)$ & 90 & $78.946(4)$ & 90 \\
\hline$\beta\left(^{\circ}\right)$ & $103.130(3)$ & $77.534(3)$ & 90 \\
\hline$\gamma\left(0^{\circ}\right)$ & 90 & $64.451(3)$ & 90 \\
\hline $\mathrm{V}\left(\AA^{3}\right)$ & $14236.5(16)$ & $5784(3)$ & $10473.9(13)$ \\
\hline $\mathrm{Z}$ & 4 & 2 & 4 \\
\hline $\mathrm{T}(\mathrm{K})$ & $110(2)$ & $110(2)$ & $110(2)$ \\
\hline$\lambda(\AA)$ & 0.71073 & 0.71073 & 0.71073 \\
\hline GOF & 1.021 & 0.991 & 1.047 \\
\hline Density (calcd) $\left(\mathrm{Mg} / \mathrm{m}^{3}\right)$ & 1.292 & 1.362 & 1.382 \\
\hline $\begin{array}{l}\text { Absorption coefficient } \\
\left(\mathrm{mm}^{-1}\right)\end{array}$ & 1.325 & 1.637 & 1.775 \\
\hline $\mathrm{F}_{000}$ & 5856 & 2484 & 4552 \\
\hline Total no Reflections & 57272 & 43951 & 24395 \\
\hline Unique Reflections & 24492 & 22790 & 5986 \\
\hline Final $\mathrm{R}$ indices* & $\begin{array}{l}\mathrm{R}_{1}=0.1171 \\
\mathrm{wR}_{2}=0.2980\end{array}$ & $\begin{array}{l}\mathrm{R}_{1}=0.0826 \\
\mathrm{wR}_{2}=0.2139\end{array}$ & $\begin{array}{l}\mathrm{R}_{1}=0.0714 \\
\mathrm{wR}_{2}=0.1784\end{array}$ \\
\hline $\begin{array}{l}\text { Largest Diff. peak and hole } \\
\left(\mathrm{e}^{-} \mathrm{A}^{-3}\right)\end{array}$ & $3.553,-0.982$ & $3.905,-2.726$ & $1.954,-1.456$ \\
\hline
\end{tabular}




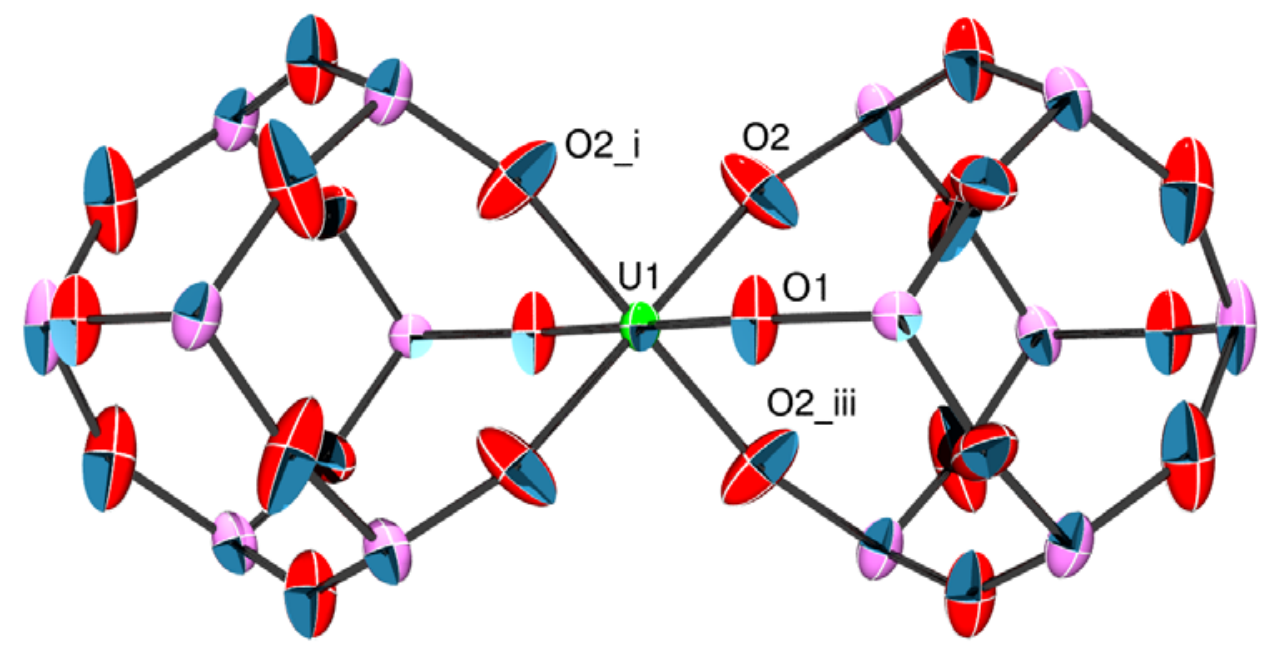

Figure S24. Solid-state molecular structure of $\mathbf{3}$ shown with $50 \%$ probability ellipsoids. All hydrogen atoms and cyclohexyl groups have been omitted for clarity. Selected bond lengths ( $\AA$ ) and angles $\left({ }^{\circ}\right): \mathrm{U} 1-\mathrm{O} 1=2.061(7), \mathrm{U} 1-\mathrm{O} 2=2.038(6), \mathrm{O} 1-\mathrm{U} 1-\mathrm{O} 2=89.6(2), \mathrm{O} 1-\mathrm{U} 1-\mathrm{O} 2 \_\mathrm{i}=$ 90.4(2), O2-U1-O2_i = 91.0(4), O2-U1-O2_iii = 89.0(4). 


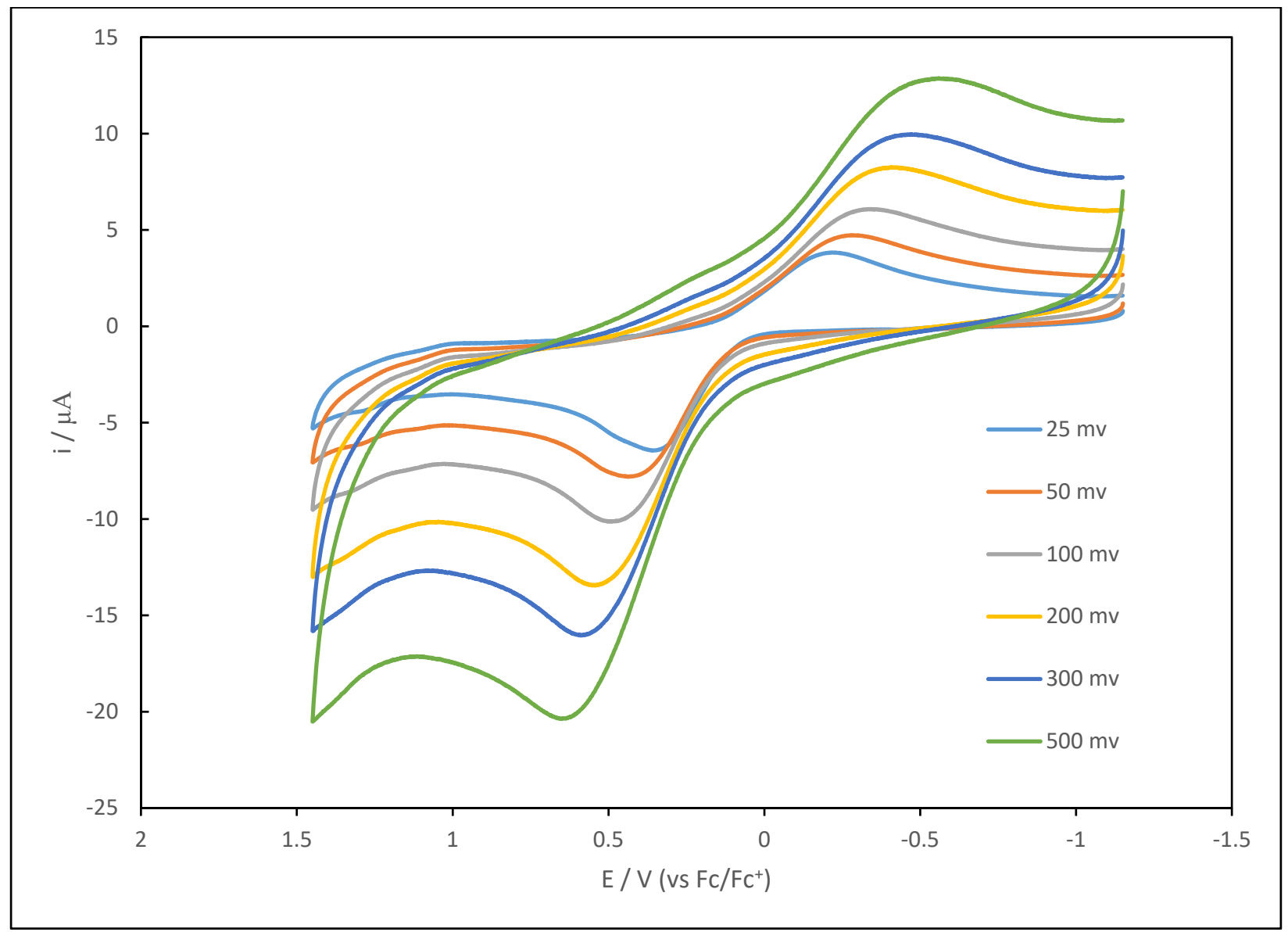

Figure S25. Partial cyclic voltammogram of the U(V/VI) oxidation event of 5 measured in $\mathrm{CH}_{2} \mathrm{Cl}_{2}$, in the presence of 2 equiv of 12-crown-4, with $0.1 \mathrm{M}\left[\mathrm{NBu}_{4}\right]\left[\mathrm{PF}_{6}\right]$ as the supporting electrolyte (vs. $\mathrm{Fc} / \mathrm{Fc}^{+}$). 
Table S3. Electrochemical parameters for $\left[\mathrm{Li}(\mathrm{THF})_{2}\right]\left[\mathrm{U}\left(\mathrm{Cy}_{7} \mathrm{Si}_{7} \mathrm{O}_{12}\right)_{2}\right](5)$ in $\mathrm{CH}_{2} \mathrm{Cl}_{2}$, in the presence of 2 equiv of 12 -crown-4 (vs. $\mathrm{Fc} / \mathrm{Fc}^{+},[\mathrm{NBu} 4][\mathrm{PF} 6]$ as the supporting electrolyte).

\begin{tabular}{lcccccc}
\hline $\begin{array}{l}\text { Oxidation } \\
\text { Feature }\end{array}$ & $\begin{array}{c}\text { Scan } \\
\text { Rate, } \mathbf{V} / \mathbf{s}\end{array}$ & $\mathbf{E}_{\mathbf{p}, \mathbf{a}}, \mathbf{V}$ & $\mathbf{E}_{\mathbf{p}, \mathbf{c}}, \mathbf{V}$ & $\mathbf{E}_{\mathbf{1} / \mathbf{2}}$ & $\Delta \mathbf{E}_{\mathbf{p}}, \mathbf{V}$ & $\mathbf{i}_{\mathbf{p}, \mathbf{a}} / \mathbf{i}_{\mathbf{p}, \mathbf{c}}$ \\
\hline 0.025 & 0.347 & -0.219 & 0.064 & 0.566 & 1.47 \\
& 0.050 & 0.424 & -0.272 & 0.076 & 0.696 & 1.47 \\
& 0.100 & 0.477 & -0.302 & 0.088 & 0.779 & 1.57 \\
& 0.200 & 0.535 & -0.361 & 0.087 & 0.896 & 1.54 \\
& 0.300 & 0.578 & -0.407 & 0.086 & 0.985 & 1.77 \\
& 0.500 & 0.637 & -0.502 & 0.068 & 1.139 & 1.95 \\
\hline
\end{tabular}




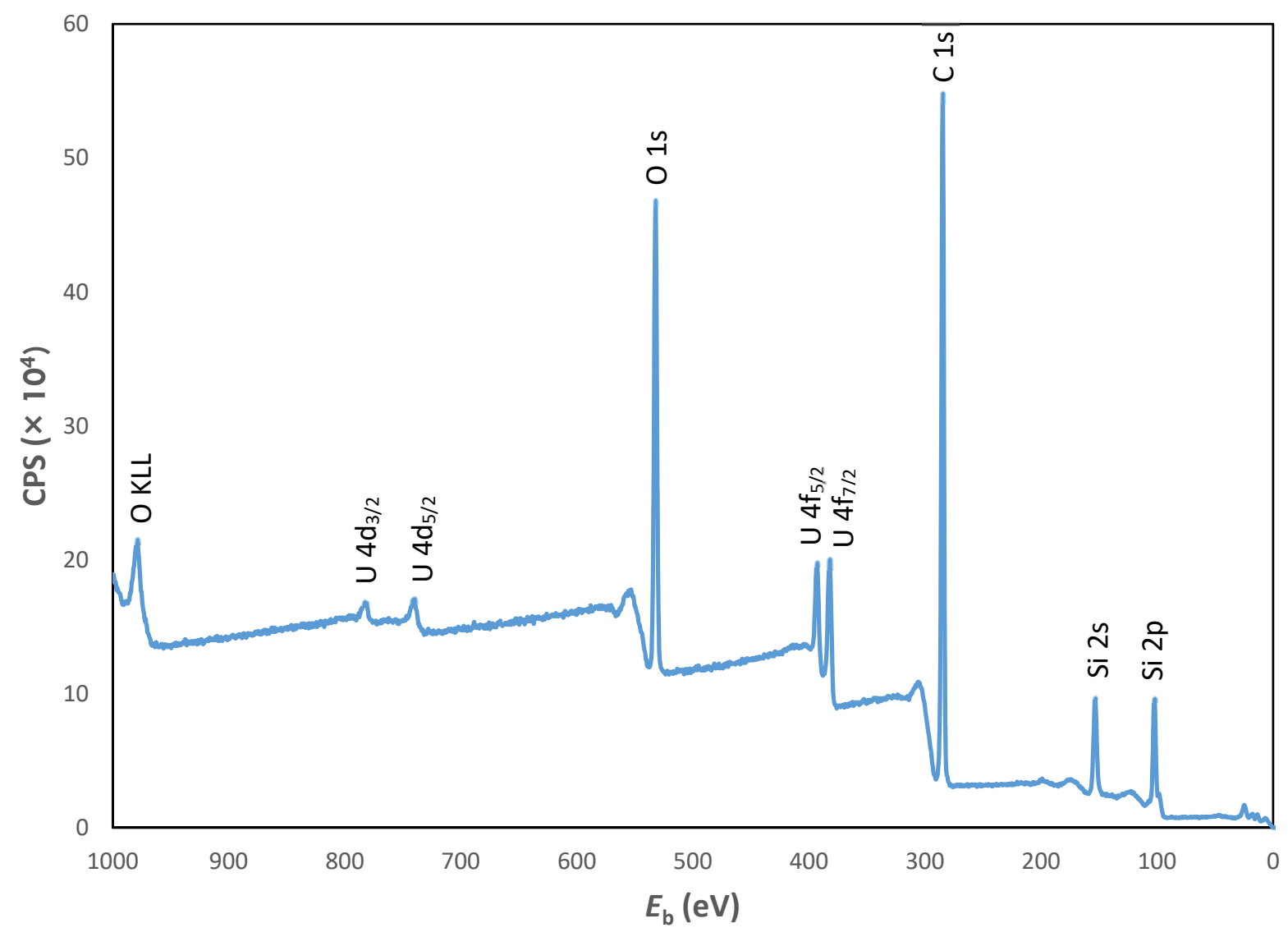

Figure S26. X-ray photoelectron spectrum of the yellow powder isolated from the reaction between $\left[\mathrm{UO}_{2}\left(\mathrm{~N}\left(\mathrm{SiMe}_{3}\right)_{2}\right)_{2}(\mathrm{THF})_{2}\right]$ and $\mathrm{Cy}_{7} \mathrm{Si}_{7} \mathrm{O}_{9}(\mathrm{OH})_{3}$.

Table S4. X-ray Photoelectron Spectroscopy (XPS) Data

\begin{tabular}{|c|c|}
\hline Assignment & $E_{\mathrm{b}}(\mathrm{eV})$ \\
\hline O KLL & 979.2 \\
\hline $\mathrm{U} 4 \mathbf{d}_{3 / 2}$ & 783.2 \\
\hline $\mathbf{U} 4 d_{5 / 2}$ & 740.6 \\
\hline O 1s & 532.0 \\
\hline $\mathrm{U} 4 \mathbf{f}_{5 / 2}$ & 393.9 \\
\hline $\mathbf{U} \mathbf{4} \mathbf{f}_{7 / 2}$ & 383.2 \\
\hline U $4 \mathbf{f}_{5 / 2}$ & 392.7 \\
\hline $\mathbf{U} \mathbf{4} \mathbf{f}_{7 / 2}$ & 382.0 \\
\hline U $4 \mathbf{f}_{5 / 2}$ & 391.3 \\
\hline $\mathbf{U} \mathbf{4} \mathbf{f}_{7 / 2}$ & 380.6 \\
\hline C 1s & 284.6 \\
\hline Si $2 s$ & 153.5 \\
\hline Si $2 p$ & 102.4 \\
\hline
\end{tabular}




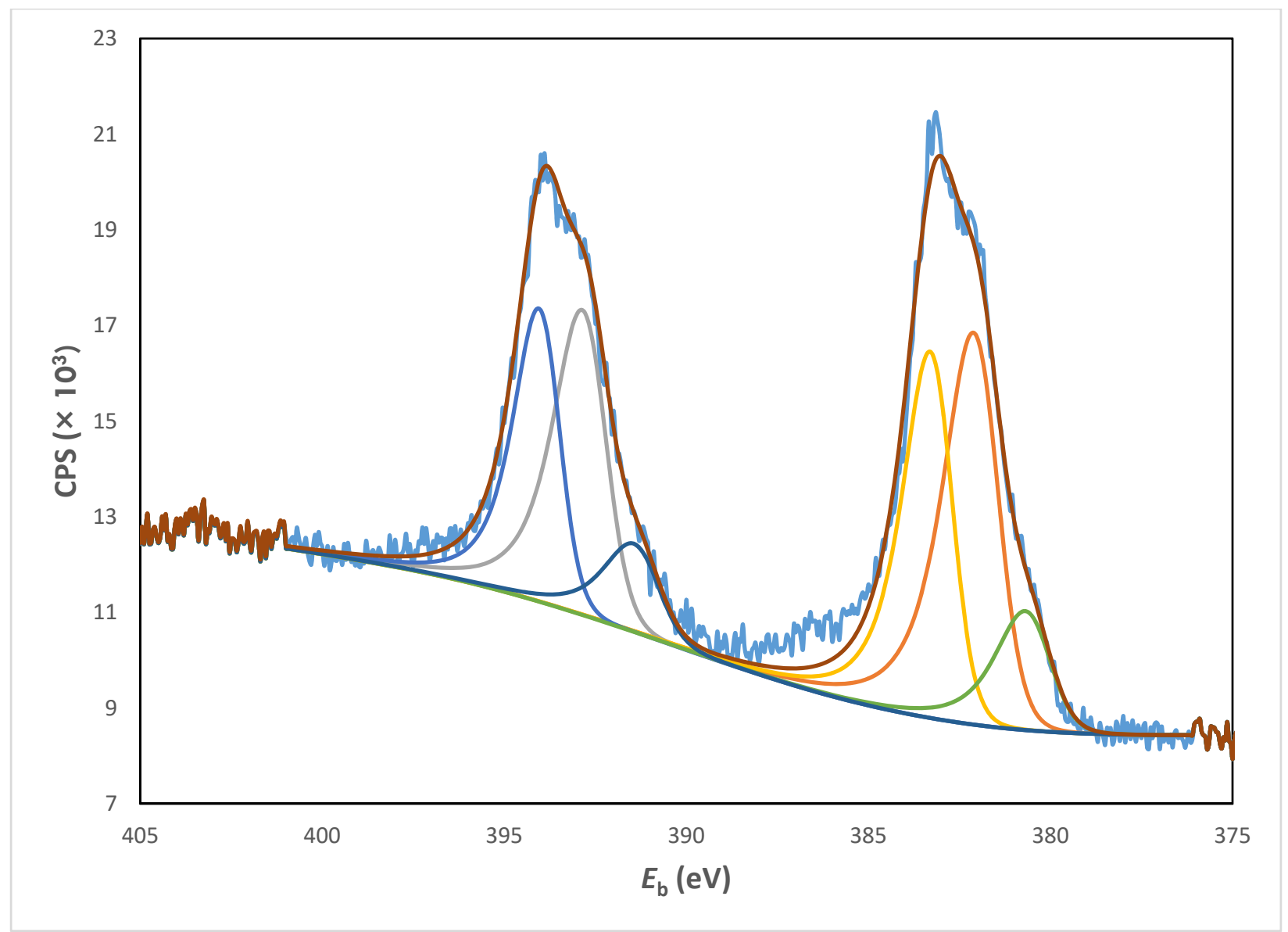

Figure S27. High resolution X-ray photoelectron spectrum of the yellow powder isolated from the reaction between $\left[\mathrm{UO}_{2}\left(\mathrm{~N}\left(\mathrm{SiMe}_{3}\right)_{2}\right)_{2}(\mathrm{THF})_{2}\right]$ and $\mathrm{Cy}_{7} \mathrm{Si}_{7} \mathrm{O}_{9}(\mathrm{OH})_{3}$.

Table S5. X-ray Photoelectron Spectroscopy (XPS) Data

\begin{tabular}{ccc}
\hline Component & Assignment & $\boldsymbol{E}_{\mathbf{b}}(\mathbf{e V})$ \\
\hline $\mathbf{A}$ & $\mathrm{U} 4 \mathrm{f}_{5 / 2}$ & 393.9 \\
& $\mathrm{U} 4 \mathrm{f}_{7 / 2}$ & 383.2 \\
$\mathbf{B}$ & $\mathrm{U} 4 \mathrm{f}_{5 / 2}$ & 392.7 \\
& $\mathrm{U} 4 \mathrm{f}_{7 / 2}$ & 382.0 \\
$\mathbf{C}$ & $\mathrm{U} 4 \mathrm{f}_{5 / 2}$ & 391.3 \\
& $\mathrm{U} 4 \mathrm{f}_{7 / 2}$ & 380.6 \\
\hline
\end{tabular}




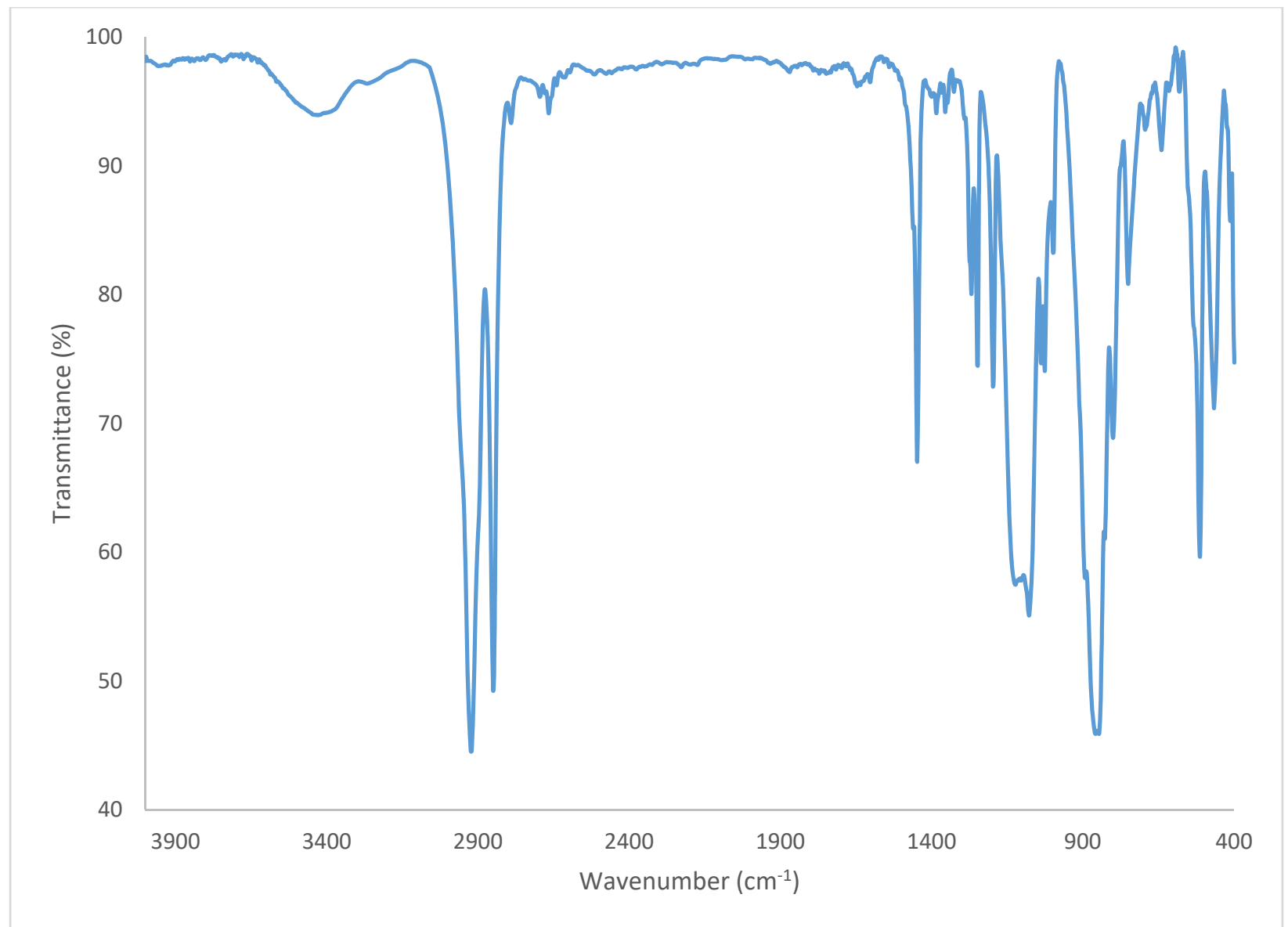

Figure S28. IR spectrum of $\mathbf{1}$ (KBr pellet). 


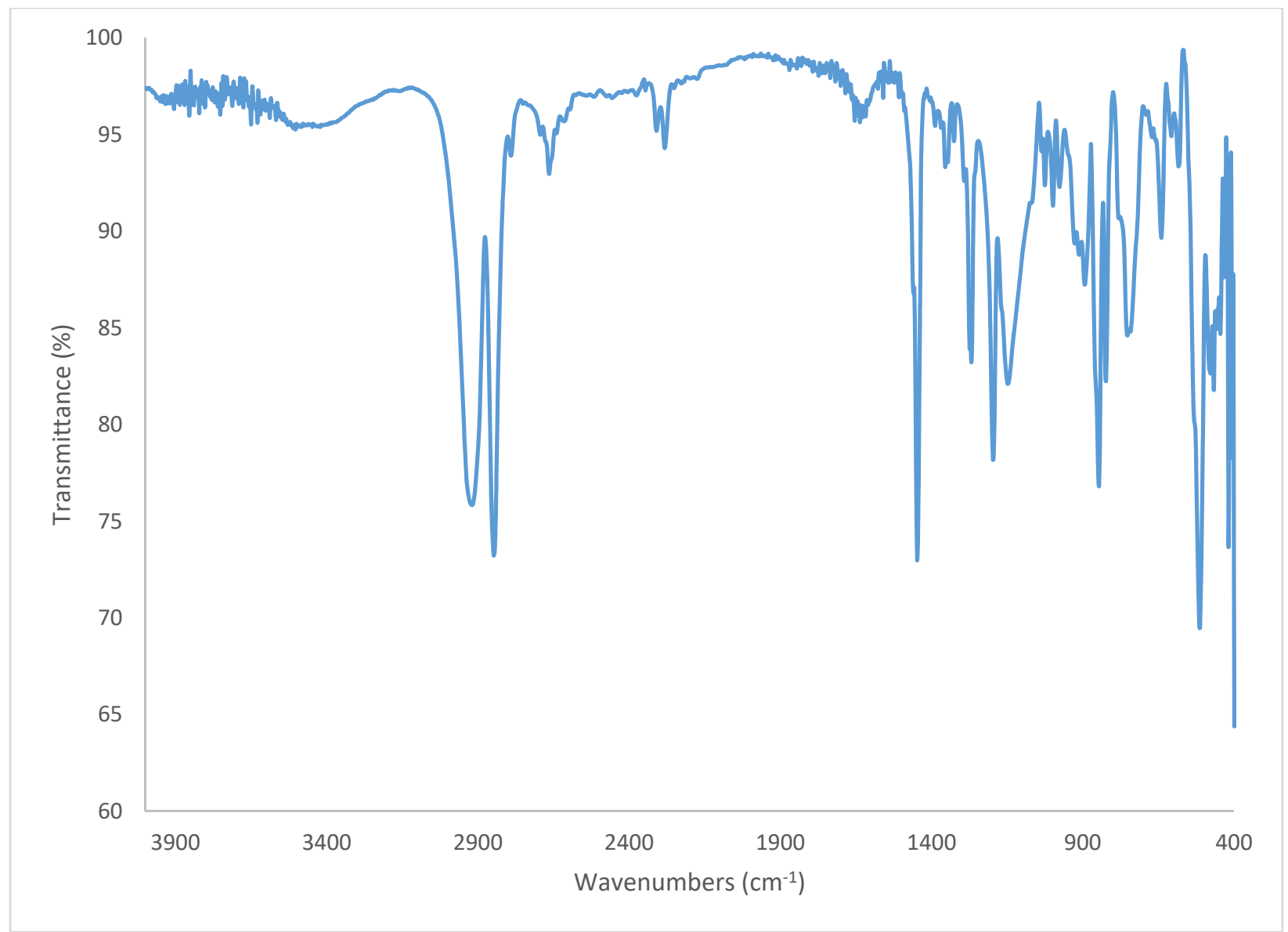

Figure S29. IR spectrum of 2 (KBr pellet). 


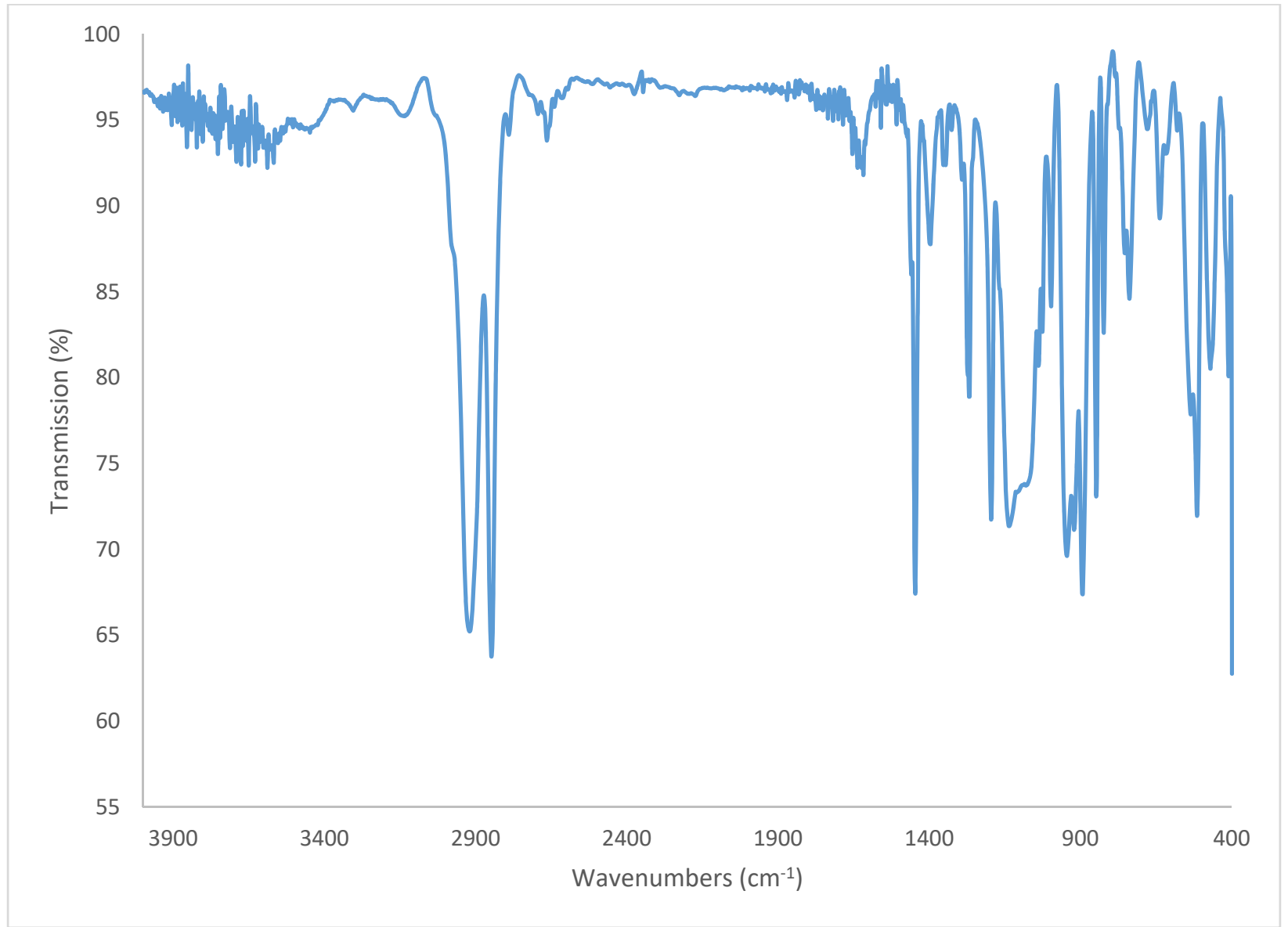

Figure S30. IR spectrum of 4 ( $\mathrm{KBr}$ pellet). 


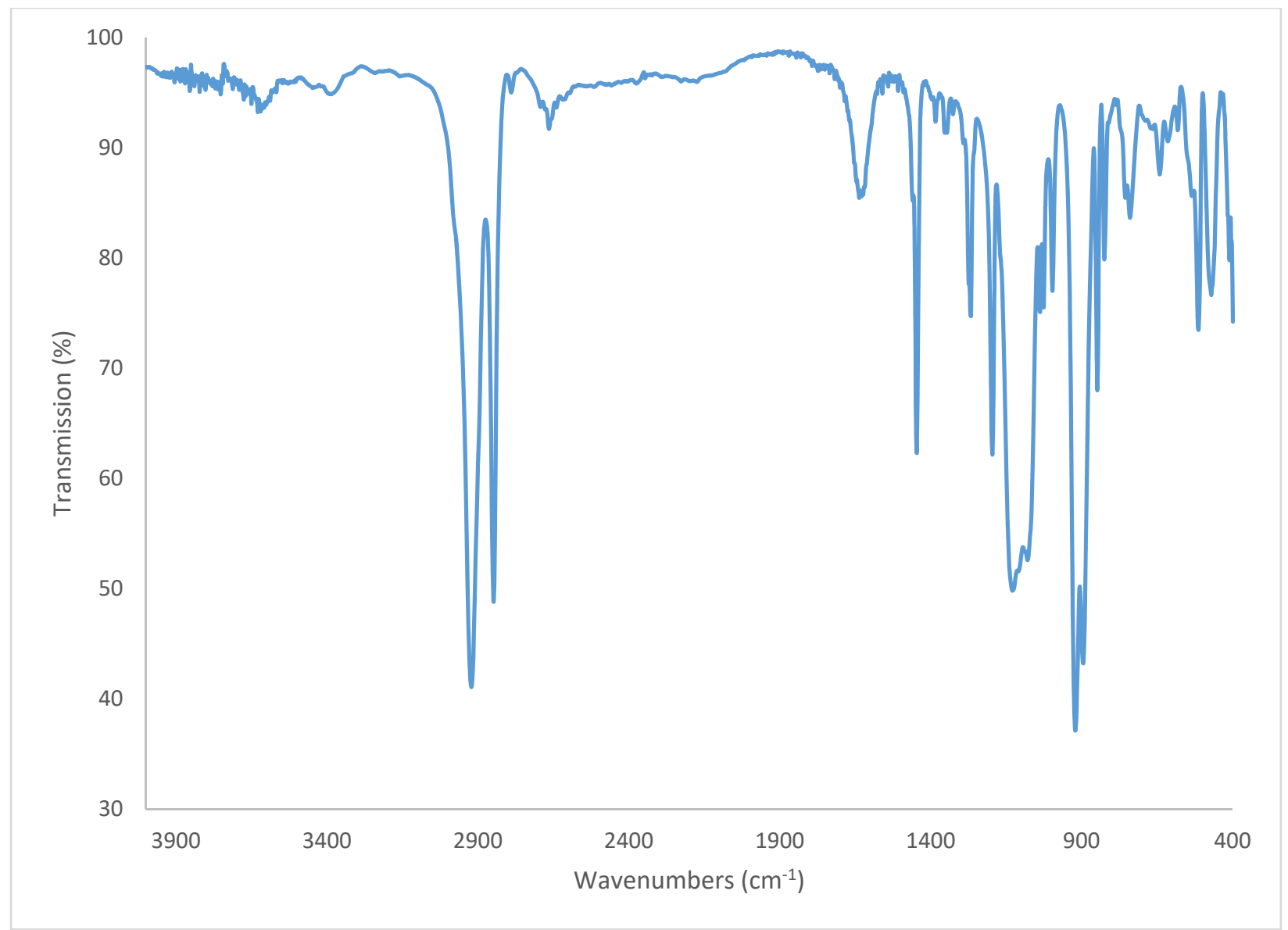

Figure S31. IR spectrum of 5 (KBr pellet). 


\section{References:}

(1) Barnhart, D. M.; Burns, C. J.; Sauer, N. N.; Watkin, J. G. Inorg. Chem. 1995, 34, 4079-4084.

(2) Fortier, S.; Wu, G.; Hayton, T.W. Inorg. Chem. 2008, 47, 4752-4761.

(3) Lam, K.; Geiger, W.E. J. Org. Chem. 2013, 78, 8020-8027.

(4) Harris, R. K.; Becker, E. D.; Cabral De Menezes, S. M.; Granger, P.; Hoffman, R. E.;

Zilm, K. W. Pure Appl. Chem. 2008, 80, 59-84.

(5) Harris, R. K.; Becker, E. D.; Cabral De Menezes, S. M.; Goodfellow, R.; Granger, P.

Pure Appl. Chem. 2001, 73, 1795-1818.

(6) SMART Apex II, Version 2.1, Bruker AXS Inc., Madison, WI, 2005,

(7) SAINT Software User's Guide, Version 7.34a, Bruker AXS Inc., Madison, WI, 2005,

(8) SADABS, Sheldrick, G. M., University of Gottingen, Germany, 2005,

(9) SHELXTL PC, Version 6.12, Bruker AXS Inc., Madison, WI, 2005,

(10) Dolomanov, O. V.; Bourhis, L. J.; Gildea, R. J.; Howard, J. A. K.; Puschmann, H. J. Appl. Cryst. 2009, 42, 339-341.

(11) Unno, M.; Alias, S. B.; Arai, M.; Takada, K.; Tanaka, R.; Matsumoto, H. Appl. Organomet. Chem. 1999, 13, 303-310. 